IV.

\title{
Genesis and influence of the canon law collection in BN lat. 13368*)
}

Von

\section{Christof Rolker}

Modern research on pre-Gratian canon law has been predominantly concentrated on a small group of chronological and systematic collections associated with known authors and/or found in many manuscripts, and within this group, most research has been done on collections available in printed editions. Yet the vast majority of pre-Gratian canonical collections are unsystematic, anonymous and survive only in single or few manuscript copies; they are for the best part unknown, and hardly any of them are edit$\left.\mathrm{ed}^{1}\right)$. There are two reasons for this imbalance. First, research is of course hampered by the absence of editions for the 'minor collections', and their seeming unimportance often discourages scholars from making the necessary effort to study them. Second, the genre itself does not respond well to the methods normally employed to analyse pre-Gratian canon law collections. These small collections lacking structure and titles were frequently combined and excerpted; the extant manuscripts preserve only one, often late, stage of this complex process. In short, one is not dealing with one authorative 'original', some 'faithful copies' and some 'divergent versions', even in the limited sense that such categories can be applied to the larger

*) I am indebted to Dr. Martin Brett and Dr. Linda Fowler-Magerl, who most generously shared with me the results of their work on the collections discussed in the following and put microfilms of the relevant manuscripts at my disposal. Dr. Brett also provided me with his provisional editions of the Ivonian collections which will hopefully be available online soon.

$\left.{ }^{1}\right)$ Cf. in general Lotte Kéry, Canonical collections of the early Middle Ages (ca. 400-1140): a bibliographical guide to the manuscripts and literature (Washington/D.C. 1999). 
collections, but rather with different stages of a set of texts transmitted at times together, at times not. Many collections of this kind thus never had the separate and distinctive existence of, for example, Burchard's Liber decretorum. Finally, a third reason why minor collections of the eleventh and twelfth centuries in particular tend to be overlooked seems to be a misconception of linear progress in the development of canon law between the time of Burchard of Worms and that of Gratian. Paul Fournier established a general model of how the 'reform collections' of the late eleventh century sought to replace Burchard's Liber decretorum, ultimately successfully ${ }^{2}$ ). According to this model, the minor collections Fournier used to dismiss as 'farragines' played little if any role in the development of canon law in the eleventh and twelfth centuries. However, the fact that Burchard compiled a comprehensive systematic collection in the early eleventh century should not obscure the fact that less sophisticated canonical collections were compiled well into the twelfth century and played indeed an important role. These collections, arranged neither systematically nor chronologically but according to their formal sources, may not represent the most sophisticated developments in canon law, but they are good evidence for the general appetite for canon law, even where only poor material was available. In any case it was through such short and idiosyncratic abbreviations that canon law was known at many places.

One such collection is that preserved in Paris, BN lat. 13368, foll. $9^{\mathrm{r}}-20^{\mathrm{v}}$. The manuscript failed to attract the attention of canon law historians until recently; Linda Fowler-Magerl describes it as 'uninviting' for good reason $^{3}$ ). It is a hasty twelfth-century copy of 338 canons, often in corrupt form, arranged in no apparent order. The largest share of material comes from the Fathers - Gregory I, Augustine, Jerome - supplemented by various synodal decrees, decretals and some canons from the capitularies. The collection is

\footnotetext{
2) Paul Fournier, Le Décret de Burchard de Worms: ses caractères, son influence, Revue d'histoire ecclésiastique 12 (1911), 451-73 \& 670-701, 689-90; idem, Un tournant d'histoire du droit 1060-1140, Nouvelle revue historique de droit français et étranger 40 (1917), 129-80, and idem, Les collections canoniques romaines de l'époque de Grégoire VII, Mémoires de l'Institut National de France, Académie des Inscriptions et Belles-Lettres 41 (1920), 271-397; they are all reprinted in his Mélanges de droit canonique, ed. Theo Kölzer (2 vols., Aalen 1983). See also Paul Fournier/Gabriel Le Bras, Histoire des collections canoniques en Occident: depuis les Fausses Décretales jusqu'au Décret de Gratien (Paris 1931/32), ii, 1 and passim.

$\left.{ }^{3}\right)$ Linda Fowler-Magerl, A selection of canon law collections compiled between 1000 and 1140: access with data processing (Piesenkofen 2003), 77.
} 
not divided into books or titles; even the division between individual canons is often hard to make out. In modern times, the manuscript was tightly bound and ploughed on all margins, so that the marginal rubrics are almost completely lost and many canons lack one or two lines of text. The manuscript was at Fleury before it came to St-Germain-des-Prés, but was most likely not written there ${ }^{4}$ ). In many respects, then, the collection in $\mathrm{BN}$ lat. 13368 resembles a typical 'minor' collection - an unsystematic florilegium of patristic and canonistic authorities. But as Fowler-Magerl pointed out on several occasions, elements of this collection (though not the manuscript itself) were used for a considerable number of canon law collections in the second half of the eleventh and the first half of the twelfth centuries. In the following, the siglum $\boldsymbol{T C}$ (taken from the Kanones database) ${ }^{5}$ ) will be used to designate the original collection, as opposed to the extant version in BN lat. 13368. Following her observations, I shall first outline the genesis of $T C$ and then its influence in the eleventh and twelfth centuries.

To understand $T C$ we must start with an examination of the extant form preserved in Paris, BN lat. 13368, though it represents a very late stage in the history of $T C$. The collection on foll. $9^{\mathrm{r}}-20^{\mathrm{v}}$ was bound together with other material at St-Germain or possibly already at Fleury. The other texts in the manuscript are not related to $T C$ and were presumably not written in the same scriptorium ${ }^{6}$ ). Even within $T C$ proper the collection in BN lat. 13368 is clearly late and composite. For ease of reference I retain Fowler-Magerl's numbering based on BN lat. 13368. Foll. $9^{\mathrm{r}}-20^{\mathrm{v}}$ contain the following material:

foll. $9^{\mathrm{r}}-9^{\mathrm{v}} \quad T C$, c. $1 \quad$ The Decretum Gelasianum ${ }^{7}$ )

fol. $9^{v} \quad T C$, cc. $2-8 \quad$ Excerpts from the Sententiae Pauli ${ }^{8}$ )

$\left.{ }^{4}\right)$ Cf. Marco Mostert, The library of Fleury: a provisional list of manuscripts (Hilversum 1989), 234; for the manuscript see also Birger Munk Olsen, L'étude des auteurs classiques latins aux XI ${ }^{\mathrm{e}}$ et XII ${ }^{\mathrm{e}}$ siècles (Paris 1982-89), ii, 652.

$\left.{ }^{5}\right) T C$ is part of Fowler-Magerl's invaluable Kanones database, the latest version of which is about to be published in the MGH Hilfsmittel series. I have silently emended some minor errors found in Kanones. It should be mentioned that users of older Kanones versions will find only TC, cc. 1-304 in the database. The $2003 \mathrm{Ka}$ nones $J$ contains the whole collection.

$\left.{ }^{6}\right)$ Cf. Mostert, Library of Fleury, 234 for references.

$\left.{ }^{7}\right)$ The text is edited in Das Decretum Gelasianum de libris recipiendis et non recipiendis, ed. Ernst von Dobschütz (Leipzig 1912). BN lat. 13368, fol. 9r is damaged and lacks the first lines.

$\left.{ }^{8}\right)$ The sententiae are edited by Paul Krüger in Collectio librorum iuris anteiustiniani in usum scholarum 2 (Berlin 1878), 41-137. 
foll. $9^{\mathrm{v}}-13^{\mathrm{v}} \quad T C$, cc. $9-124$

foll. $13^{\mathrm{v}}-14^{\mathrm{r}} \quad T C$, c. 125

foll. $14^{\mathrm{r}}-16^{\mathrm{v}} \quad T C$, cc. $126-96$

foll. $16^{\mathrm{v}-18^{\mathrm{v}}} \quad T C$, cc. $197-240$

foll. $18^{\mathrm{v}}-19^{\mathrm{v}} \quad T C$, cc. $241-303$

foll. $19^{\mathrm{v}}-20^{\mathrm{v}} \quad T C$, cc. $304-38$

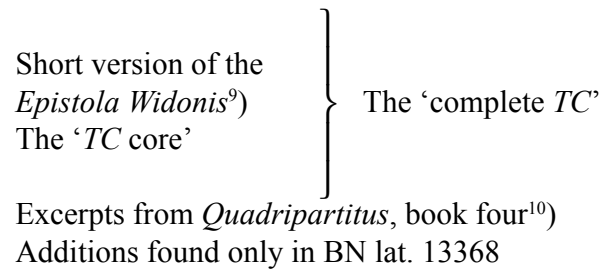

As will become clear in the following, the distinction between the elements in this table derives from other collections drawing on $T C$. These all use shorter and more archaic versions of $T C$ than that preserved in $\mathrm{BN}$ lat. 13368. Indeed, three earlier stages can be inferred: a 'core' of ca. 70 canons (TC, cc. 126-96); a 'complete form' of TC containing ca. 230 canons ( $T C$, cc. 9-240 and probably also c. 1), and an 'augmented $T C$ ' with an additional set of ca. 60 canons taken from the Quadripartitus (TC, cc. 241-303). The last canons in BN lat. 13368 (TC, cc. 304-38) are found in no other collection related to $T C$; in the following, they will largely be ignored. Whether the Decretum of Gelasius (TC, c. 1) was part of the 'complete $T C$ ' and the question if and when the excerpts from the Roman jurist Paul (TC, cc. 2-8) were added to $T C$ will be discussed in due course.

To begin with, three excerpts and the so-called Appendix Seguntina ultimately all drew on a common source that was very similar to $T C$, cc. 126-96, the 'core', but show no sign of the influence of the texts in the 'complete' text defined above ${ }^{11}$ ). Obviously, this part of $T C$ enjoyed separate circulation. Its most recent text is the 'Ambrosian' claim that anyone contradicting

$\left.{ }^{9}\right)$ Ed. Friedrich Thaner in MGH, Libelli de lite, i, 1-7. It was presumably part of the ' $T C$ core' but ignored by the four collections drawing on it as will be discussed below.

$\left.{ }^{10}\right)$ Cf. Fowler-Magerl, Fine distinctions and the transmission of texts, ZRG 114 Kan. Abt. 83 (1997), 146-86, 173, n. 35. For the collection cf. Franz Kerff, Der Quadripartitus: ein Handbuch der karolingischen Kirchenreform: Überlieferung, Quellen und Rezeption (Sigmaringen 1982). Book iv is edited in Antiqua canonum collectio qua in libris de synodalibus causis compilandis usus est Regino Prumensis, ed. Emil Ludwig Richter (Marburg 1844), 3-43. For its sources cf. Kerff, Quadripartitus, 93-102. For the relation between book four and the whole collection cf. ibid., 38-46 and Rudolf Pokorny, Eine Kurzform der Konzilskanones von Trosly (909): zur Reformgesetzgebung in der ausgehenden Karolingerzeit, Deutsches Archiv für Erforschung des Mittelalters 42 (1986), 118-44, 124, n. 30. The TC compiler copied the canon numbers of the Quadripartitus which are in part preserved in $\mathrm{BN}$ lat. 13368. As there is no reference to the book number, one could reasonably suspect that the formal source was an independent copy of book four.

$\left.{ }^{11}\right)$ Corrected from Fowler-Mager1, Fine distinctions, 173, n. 35, who suggested that cc. $125-338$ constituted an 'older core'. 
the Roman church is to be called heretic, a phrase famously first cited by Gregory VII in his Dictatus papae ${ }^{12}$ ). This places the TC core after ca. 1075, or possibly after ca. 1080, the first known use of the phrase by Gregory in a letter to Hirsau $\left.{ }^{13}\right)$. The rest of the $T C$ core does not contain material more recent than the Epistola Widonis which was written ca. $1031^{14}$ ). It is more likely that these canons represent an older core than an excerpt of the complete form; there is nothing that would make the middle part stand out once it was augmented at the beginning and the end. However, TC, c. 125 (the Epistola Widonis) was originally part of the $T C$ core, as the following c. 126 is a Gregory text drawn from the Epistola Widonis ${ }^{15}$ ). The collections which draw on the $T C$ core normally begin with c. 126; either c. 125 was not part of the 'core', or the compilators of the excerpts ignored this letter.

The three excerpts drawing on the 'core' are preserved in Paris, BN lat. 13414, BN lat. 14193, and Antwerp, Plantin-Moretus M.82. They form a group of which BN lat. 13414 seems to be closest to the common source, as the other two collections have only very few $T C$ canons not found there and $\mathrm{BN}$ lat. 13414 preserves more complete texts of several canons they share. The two copies now at Paris share most $T C$ material and also some other texts not found in the Antwerp manuscript ${ }^{16}$ ). The Appendix Seguntina represents an independent tradition of the $T C$ core; it draws on the same range of canons as the Paris/Antwerp excerpts, but often selects different ones. Both traditions go back to a common source that contained not only $T C$, cc. 126-96 but also additional material not found in $T C$; this is the most likely explanation for some canons the Appendix and the three minor collections have in com-

$\left.{ }^{12}\right)$ JL 5167 and Dictatus papae, c. 26, both in Das Register Gregors VII., ed. Erich Caspar (Berlin 1920), ii, 504-5 and i, 207, respectively.

13) The Dictatus papae is placed between two letters written 2 and 4 March 1075. JL 5167 to Abbot William of Hirsau was written 8 May 1080.

${ }^{14)}$ Cf. Thaner (n. 9), i, 2.

$\left.{ }^{15}\right) \mathrm{BN}$ lat. 13368, fol. 14ra: Gregorius in registro de simoniacis. Quisquis per pecunias ordinatur ad hoc - hoc periculosum flagitium. This text combines the first two Gregory I texts quoted in the Epistola Widonis, ed. Thaner, 4 (cf. John T. Gilchrist, Die Epistola Widonis oder Pseudo-Paschalis: der erweiterte Text, Deutsches Archiv für Erforschung des Mittelalters 37, 1981, 576-604, 594). Both fragments are genuine (from JE 1747 and 1859, respectively) but the combination, and the form of the second fragment leave no doubt that both texts were taken from the Epistola Widonis and not the register.

$\left.{ }^{16}\right)$ Texts found in BN lat. 13414 and 14193 but not the Antwerp manuscript are: $T C$, cc. $52,130,138-42,145,147,155 \mathrm{a}, 159 \mathrm{a}-\mathrm{b}, 160-1,162 \mathrm{a}, 165 \mathrm{~b}, 166,174,178-$ $80,182-6$ and 188; after $T C$, cc. $130,131,174$ and 179 both manuscript share texts not found in any other $T C$ collection. 
mon $^{17}$ ). A series of four long Gregory I pieces common to BN lat. 13413 and the Appendix Seguntina (though no other collection) was presumably also transmitted with the $T C$ core $^{18}$ ). Another common feature of the $T C$ version used is that the sequence of canons was slightly different from that in $\mathrm{BN}$ lat. $\left.13368^{19}\right)$.

To turn to the single manuscripts, BN lat. 13414 was written in the twelfth century and comes from the monastery of St Martin at Séez $\left.{ }^{20}\right)$. The collection on foll. $122^{\mathrm{r}}-152^{\mathrm{r}}$ contains 56 canons most likely taken from the $T C \mathrm{core}^{21}$ ); they make about a fifth of the whole collection which is drawn from decretals, synodal decrees and patristic writings, with an appendix containing the decrees of Clermont 1095 and a unique form of the canons of the Council of Westminster of $1102^{22}$ ). The excerpts are scattered throughout the collection in short series normally preserving the order of $T C$. The first three canons are genuine or supposed Augustine excerpts, followed by TC, c. 126, the first canon of the TC core after the Epistola Widonis also found at beginning of the Appendix Seguntina ${ }^{23}$ ).

BN lat. 14193 was copied in the twelfth century maybe in St Remi, Reims $\left.{ }^{24}\right)$. The collection on foll. $87^{\mathrm{v}}-94^{\mathrm{v}}$ opens with eight excerpts from the

${ }^{17}$ ) More complete forms of Appendix Seguntina, cc. 79-80 are found in BN lat. 14193, fol. 90r, BN lat. 13413, fol. 124r, and Antwerp, Plantin-Moretus M.82, fol. 96v; Appendix Seguntina, cc. 18 and 20 are found in BN lat. 14193, fol. 89v and BN lat. 13413 , foll. $122 \mathrm{v}-123 \mathrm{r}$, respectively; the Antwerp manuscript and all collections depending on the complete $T C$ lack these canons. Seemingly both canons were part of the $T C$ core but not the complete $T C$.

${ }^{18)}$ BN lat. 13413, foll. 149r-150v = Appendix Seguntina, cc. 45-8.

$\left.{ }^{19}\right)$ The Augustine texts $T C$, cc. 154-8 were displaced. In BN lat. 13413, fol. 126v, BN lat. 14193, fol. 91r, and the Appendix, the canons now numbered cc. 25-6 and 159 follow immediately after c. 153 . The Antwerp manuscript lacks $T C$, cc. 154-8.

${ }^{20}$ ) Robert Somerville, The councils of Urban II: Decreta Claromontesia (Amsterdam 1972), 85.

$\left.{ }^{21}\right)$ Namely, $T C$, cc. 127-36, 138-45, 147, 149-50, 153-7, 159-74, 177-80, 182-8, 190-3 and 196. (Corrected from Fowler-Magerl, see n. 10 above, 174, n. 37.)

${ }^{22}$ ) For Clermont cf. Somerville, Councils of Urban II, 85 (manuscript) and 8998 (edition); for Westminster cf. Councils and synods with other documents relating to the English church I: A.D. 871-1204, ed. Dorothy Whitelock, Martin Brett and Christopher Nugent Lawrence Brooke (2 vols., Oxford 1981), ii, 671-2 (manuscript) and 679-81 (edition).

${ }^{23}$ ) BN lat. 13414, fol. 122r. I have not found any parallel to the first two canons (Iracundiam mitigare libidinem fugere - magna martyrii est; Familiaritas et collocutio mulierum - condemnatur a domino); the third is an incomplete form of $T C, \mathrm{c}$. 193.

${ }^{24}$ Somerville, Councils of Urban II, 32. 
Collectio Lanfranci which are numbered according to this source ${ }^{25}$ ). A second hand has numbered the whole collection, though not very accurately, to c. 66. Not all canons are numbered separately, and the division of canons is sometimes difficult to make out; in total the collection consists of some 100 fragments, 39 of which are from the $T C$ core $^{26}$ ). After the Collectio Lanfranci texts and some other canons not from $T C$, the parallels to the other $T C$ collections begin with $T C$, c. $126^{27}$ ). BN lat. 14193 and $\mathrm{BN}$ lat. 13414 are closely related; both tend to select the same TC canons; they also have some other texts in common that may have been transmitted with the $T C$ core $^{28}$ ). Normally, BN lat. 13414 has longer series of canons and/or more complete texts $^{29}$ ). However, BN lat. 13414 itself was not the formal source of BN lat. 14193 since it lacks five $T C$ canons found there ${ }^{30}$ ).

The third related collection is the very small one in Antwerp, PlantinMoretus M.82, foll. $95^{\mathrm{v}}-100^{\mathrm{r}}$. It is an appendix to a copy of book four of the ninth-century Quadripartitus made in the twelfth century, presumably in North-Eastern France ${ }^{31}$ ). The collection contains only 44 canons, including

$\left.{ }^{25}\right)$ Collectio Lanfranci, i.54, cc. 1-7 (Cambridge, Trinity College, B.16.44 (405), pp. 85-7) = BN lat. 14193, foll. 87r-88r.

$\left.{ }^{26}\right) \mathrm{TC}$, cc. 17, 52, 110-1, 129 (incomplete), 130, 133-4, 136, 138-42, 145-7, 153, 155, 159 (incomplete), 160-1, 162 (incomplete), 165 (incomplete), 166, 169 (incomplete), 170-4, 178-80, 182-6, 188 and 212.

${ }^{27}$ ) BN lat. 14193 , fol. $89 \mathrm{v}$.

${ }^{28)} \mathrm{BN}$ lat. 14193, fol. 91v, and BN lat. 13414, fol. 128r contain the same two canons from Evaristus and Gregory I, respectively, and both place them between $T C$, cc. 179-80; no other collection related to TC contains either text. Another example is the displaced canon $T C$, c. 166, which both BN lat. 13414, fol. 129r, and BN lat. 14193, fol. 92r place between $T C$, cc. 186 and 187 (or 188, respectively, as BN lat. 14193 lacks TC, c. 187); BN lat. 13414, fol. 122r and BN lat. 14193, fol. 89v both have a short Leo I canon before TC, c. 128: Qui alios ab errore non revocat seipsum errare demonstrat. This canon is not contained in the other TC collections.

${ }^{29}$ ) E.g. the series $T C$, cc. 126-44. BN lat. 13414, foll. $122 \mathrm{r}-124 \mathrm{v}$ has all canons except the second part of TC, c. 129 and the complete c. 137. BN lat. 14193 lacks these both texts plus the third part of TC, c. 129 and TC, cc. 131-2, 135 and 143-4. $T C$, cc. 129 and 137 are an integral part of TC as they are present in the Tarraconensis and BN lat. 13368; c. 129 is also found in the Palermo manuscript as c. 40, and c. 137 is also found in the Antwerp manuscript, fol. 96v. BN lat. 13413 has the complete form of most $T C$ canons which are shortened in BN lat. 14193 (see above, n. 22).

${ }^{30}$ ) TC, cc. 17 (BN lat. 14193, fol. 93r), 110-1 (fol. 93r), 146 (fol. 91v) and 212 (fol. $92 \mathrm{v})$.

${ }^{31}$ ) Cf. Raymund Kottje, Eine Antwerpener Handschrift des Quadripartitus Lib. IV, Bulletin of medieval canon law n.s. 6 (1976), 65-7; Kerff (n. 10), 15-8; Pokorny (n. 10), 124, n. 30. 
sixteen canons taken from the $T C$ core, only one of which cannot be found in $\mathrm{BN}$ lat. $13414^{32}$ ). The Antwerp collection and BN lat. 14193 often select the same $T C$ canons, but each also excerpts texts not found in the other ${ }^{33}$ ). The first canon in Antwerp is not found in any other collection related to $T C^{34}$ ), but the second is $T C$, c. 126, the first canon of the $T C$ core (after the Epistola Widonis).

While the origin of these three closely related minor collections drawing on the $T C$ core may be considerably earlier than the manuscripts which contain them, the Appendix Seguntina is clearly late. It is an appendix to the Panormia transmitted with three Spanish copies which also contain decrees from the councils of Poitiers 1100 and Toulouse $1119^{35}$ ). While Fransen assumed a French origin of the Appendix some time after 1119, Palacios argued for an origin 1148x1166 in Spain ${ }^{36}$ ). The Appendix has been associated with Poitiers because of the presence of the Poitevin decrees and parallels to the Tarraconensis $I I^{37}$ ). However, it is by no means certain that the latter originated in Poitiers. Most parallels between the Appendix and Tarraconensis II are due to their common source, $T C^{38}$ ).

Like the three copies discussed above, the Appendix draws mainly on what I call the ' $T C$ core'. The opening canon of the Appendix Seguntina is from the beginning of the ' $T C$ core' $\left.(T C, \text { c. } 126)^{39}\right)$, followed by seventy more canons

$\left.{ }^{32}\right) T C$, cc. 126, 128-9, 131-6, 137 (not in BN lat. 13414), 153 and 169-73.

${ }^{33}$ ) E.g., TC, c. 52 (BN lat. 14193, fol. 90r) and c. 126 (Antwerp, Plantin-Moretus M.82, fol. 95v).

${ }^{34}$ ) Antwerp, Plantin-Moretus M.82, fol. 95v: Decretum Calixti. Errant enim qui putant Domini - adiciet ut resurgat; variant forms of this letter $(\mathrm{JK} \uparrow 86$; ed. in Decretales Pseudo-Isidorianae et Capitula Angilramni, ed. Paul Hinschius, Leipzig 1863, 142) are common.

${ }^{35}$ ) Cf. Peter Linehan, The synod of Segovia (1166), Bulletin of medieval canon law n.s. 10 (1980), 31-44, 39-42; Gérard Fransen, Appendix Seguntina, Liber Tarraconensis et Décret de Gratien, Revista española de derecho canónico 45 (1988), 31-4; Fowler-Mager1, Selection (n. 3), 184.

${ }^{36}$ ) Fransen, Appendix Seguntina, 31-4; Arturo Bernal Palacios, La redacción breve del c. "In die surrectionis" en las colecciones canónicas pregracianas, in: Proceedings of the ninth international congress of medieval canon law: Munich, 13-18 July 1992, ed. Peter Landau and Jörg Müller (Vatican City 1997), 923-52, 936.

${ }^{37}$ ) Cf. Fowler-Mager1, Selection (n. 3), 182, and Palacios, La redacción breve, 934 and 944.

${ }^{38}$ ) The canon 'In die resurrectionis' discussed by Palacios has nothing to do with $T C$.

${ }^{39}$ ) This Gregory I canon is an excerpt taken from the Epistola Widonis found in several $T C$-related collections: BN lat. 13414, fol. 122r (incomplete); Antwerp, 
corresponding to complete forms or fragments of some fifty $T C$ canons, often in the sequence of $T C^{40}$ ). However, among these there are ten canons not taken from the core of $T C$ which do occur in the complete form of $T C$. Their small number and their scattered distribution in the Appendix do not suggest that they were drawn from the 'complete $T C^{\prime 41}$ ). The Appendix contains 40 of the 70 canons of the 'core' as opposed to a mere ten from the remaining 170 $T C$ canons, and shares several characteristics with the other excerpts drawing only on the $T C$ core discussed above. Therefore I assume that the Appendix depends on a formal source very similar to the $T C$ core; the remaining ten canons presumably are due to cross-contamination from the complete $T C$ or elsewhere, the exact transmission of which remains obscure.

These Paris/Antwerp excerpts and the Appendix Seguntina are the only known witnesses to the $T C$ core. As sketched above, this core was later augmented to form what I call the 'complete $T C$ ', enlarged by the addition of cc. 9-240 and probably also the Decretum Gelasianum. This part of the 'complete $T C^{\prime}$ 'must have been compiled after 1059 , for its most recent material comes from Nicholas' II synod in that year ${ }^{42}$ ). It may well have had independent circulation before it was juxtaposed to the $T C$ core, but if so, no witnesses are known. Its terminus ante quem is its employment for the Tripartita $A$ in the mid-1090s; most other collection drawing on $T C$ cannot be dated with certainty. As the genesis of most collections drawing on the complete $T C$ is more or less obscure, the sequence they are discussed in here does not imply a chronological order.

Plantin-Moretus M.82, fol. 95v; Appendix Seguntina, c. 1; Tripartita A1.55, c. 39; BN lat. 13368, fol. 14ra. It is not, as Fransen, Appendix Seguntina, 32 claimed, a misattribution.

${ }^{40}$ ) Appendix, cc. 1 (= TC, c. 126), 4 (c. 147a), 5 (c. 146a), 8-9 (cc. 151-2), 10 (c. 194), 11-6 (cc. 127-8), 18 (c. 128A, see above), 19 (c. 130), 20 (c. 130A, see above), 21-3 (cc. 149-50), 24-5 (c. 153), 26-34 (c. 159-65, partly fuller), 36 (c. 145), 37 (c. 181), 38-9 (c. 147), 40 (c. 184), 41-2 (cc. 186-7), 44 (c. 192A), 45-8 (parallel to the Paris/Antwerp excerpts, see above), 58 (c. 125), 62 (c. 212), 68 (c. 234.2), 69 (c. 196.1a), 71 and 73-6 (cc. 131-5), 77 (c. 190), 78-81 (c. 136, 137A, 137B, 138), 82-3 (c. 143-4), 84-7 (c. 155-8), 91-3 (c. 211), 94-8 (c. 176-9, rearranged), 99 (c. 146.3, variant), 100 (c. 214), 101 (c. 233) and 102 (c. 234.1).

$\left.{ }^{41}\right)$ Appendix, cc. 7 (=TC, c. 238), 62 (c. 212), 68 (c. 234b), 91-3 (fragments of TC, c. 211), 100-2 (cc. 214, 233 and 234a). The parallels are limited to TC, cc. 197-240, i.e. the part between the ' $T C$ core' and the Quadripartitus excerpts in $T C$. One could suspect that this part enjoyed separate circulation, and in the twelfth century this part and the $T C$ core may have been transmitted together. On the other hand, the Appendix normally follows the order of the $T C$ core, but not in the case of these canons.

${ }^{42}$ ) TC, cc. 236-8; Fowler-Mager1, Fine distinctions (n. 3), 173. 
Compared to the extant version in BN lat. 13368, the complete $T C$ still lacked some material. The Sententiae Pauli fragments (TC, cc. 2-8) were presumably not part of this $T C$ version. As these canons are not found in any other collection certainly depending on $T C$ I hesitate to treat them as an integral part of TC. By the same token, the Quadripartitus excerpts (TC, cc. 240-304) were added at a relatively late stage, the 'augmented $T C$ '. They are found in BN lat. 13368, the Tarraconensis II and a manuscript of the Caesaraugustana II, as will be discussed below; all other collections of the $T C$ group take nothing from these ca. 60 canons.

The most famous collection clearly drawing on the complete $T C$ is Tripartita $A$, compiled before the mid-1090 $\mathrm{s}^{43}$ ). The exact relationship between these collections is complex, but there is evidence that $T C$ was used for the earliest discernible version of Tripartita $A^{44}$ ). The clearest evidence for the employment of $T C$ derives from a substantial block of Gregory I found in both collections, as Fowler-Magerl was the first to discover ${ }^{45}$ ). From my study of the manuscripts related to $T C$ I can not only confirm her findings but also supplement them. About half the Gregory I section in Tripartita $A$ (Tripartita A1.55, cc. 22-81) is also found in $T C$, which in turn contains only one Gregory I canon not found in the Tripartita ${ }^{46}$ ). To be precise, the extant

${ }^{43}$ ) Cf. Fournier, Les collections attribuées à Yves de Chartres, Bibliothèque de l'École de Chartes 57/58 (1896/97), BEC 57, 645-98; BEC 58, 26-77, 293-326, 41044 \& 624-76, BEC 57, 677; Brett, The Berkeley Tripartita, Bulletin of medieval canon law n.s. 16 (1986), 89-91, 46; idem, Urban II and the collections attributed to Ivo of Chartres, in: Proceedings of the eighth international congress of medieval canon law: San Diego, University of California at La Jolla, 21-27 August 1988, ed. Stanley Chodorow (Vatican City 1992), 27-42, 39-46.

${ }^{44)}$ See below n. 50.

$\left.{ }^{45}\right)$ Fowler-Magerl, Fine distinctions (n. 10), 173.

$\left.{ }^{46}\right) T C$, c. $93=\mathrm{BN}$ lat. 13368, fol. 12rb: Ut nemo ex datione pecuniae ad sacrum ordinem audeat accedere. Ex epistula Gregorii papae. Nemo ad sacrum ordinem ex datione pecuniae - canonum decretam damnetur. Unlike most canons in BN lat. 13368, this text has no parallel in any other canonical collection related to $T C$. The Kanones database indicates a parallel to the collection in Vat. lat. 3832 and Assisi, BC 227, where it is attributed to the council of Carthage. The partial edition by Jean Bernhard, La collection en deux livres (Cod. Vat. lat. 3832), Revue de Droit canonique 12 (1962), 9-601, does not extend to this part of the collection. See now Fowler-Magerl, The restauration of the canon law collection in the mss Vat. lat. 3832 and Assisi BC 227, in: Grundlagen des Rechts: Festschrift für Peter Landau, ed. Richard H. Helmholz et al. (Paderborn 2000) 179-203. Another, potentially more interesting parallel is that to the Sinemuriensis, where the canon is shorter but has the same rubric and inscription as TC (according to Kanones). 
BN lat. 13368 contains 55 of these 60 canons. At least two more can be inferred to have been in the $T C$ version used by the compiler of the Tripartita, since they are found in BN lat. 14193; this excerpt of the TC core has only a small number of $T C$ canons and often incomplete texts, but few canons which do not occur in the other collections of the TC group. In Tripartita, the two canons are found in the middle of a sequence of other canons taken from $T C$, as will be shown later ${ }^{47}$ ).

Even without this inference, the textual parallels are intriguing, and the sequence of canons leaves no doubt that $T C$ and Tripartita are intimately related. In the unsystematic $T C$ the canons are widely scattered through the collection, but most of them occur in the very order of Tripartita $A^{48}$ ). This suggests one of three possibilities: either $T C$ could be an extract of Tripartita $A$, or both collections could depend on a common source, or Tripartita A employed a copy of $T C$ itself as a formal source. The chaotic order of canons in $T C$ and the fact that the parallels are limited to one section of the relevant Tripartita $A$ section makes the first possibility unlikely. In principle, $T C$ could of course depend on Tripartita A, yet it would be strange that the compiler should limit himself to an arbitrary section of a well-ordered collection, only to distribute these canons seemingly at random over the whole range of his collection. Better evidence, however, is available if we examine the canons in question more closely.

Almost all texts in Tripartita A1.55 are, as one would expect, genuine or forged texts of Gregory I. Some, however, are not; and this misattributed material in Tripartita $A$ can be used to determine the direction of dependence. In the series cc. 22-81, there are two such texts; one is c. 29 , which is in fact from Gregory II (JE 2174), and the other, c. 32, an extract from Ps.-Gregory IV (JE $† 2579)$. As mentioned above, $T C$ contained 57 of the 60 canons found in Tripartita A1.55, cc. 22-81, so only three canons are missing. Was TC an almost complete extract of the middle part of Tripartita A1.55? The three canons not found in $T C$ strongly suggest that this is not the case. For the three canons 'omitted' are cc. 29, 31 and 32, only the second of which is genuine. This can hardly be regarded as accidental, and almost certainly excludes the

\footnotetext{
${ }^{47}$ ) The canons correspond to Tripartita A1.55, cc. 75-6 and are found in BN lat. 14193, fos $94 \mathrm{r}$ and $94 \mathrm{v}-95 \mathrm{r}$, respectively; in the source used for the Tripartita, they would have been after $T C$, c. 211 (=TC, cc. $211 \mathrm{~A}$ and $211 \mathrm{~B})$.

${ }^{48}$ ) The parallels, in Tripartita sequence, are: TC, cc. 103-6, 26, 11-2, 139, 42, 67-9, 113-4, 126-8, 145-6, 160, 162, 167, 170-4, 179-88, 190-1, 195, 211, 211A-B (see last note), 199, 222, 229-30, 235. The different sequence is due to the rearrangement of canons in Tripartita.
} 
idea that $T C$ depends on Tripartita: the compiler of $T C$, if he drew on Tripartita, could hardly have picked Gregory I canons only and deliberately dismissed cc. 29 and 32 as spurious. The compiler of Tripartita A, presumably following his formal sources ${ }^{49}$ ), regarded these two canons to be authentic texts from Gregory I and therefore put them into Tripartita A1.55; no later user would be able to tell them from the surrounding Gregory I material.

So either Tripartita A employed TC or both depend on a common source (' $X$ '). What would $X$ have looked like? It would have contained all Gregory I texts common to Tripartita $A$ and BN lat. 13368 plus the three 'Gregory' canons not found in the latter but in Tripartita $A$. It could not have contained much more material, for otherwise it would be hard to explain why the compilers of $T C$ and Tripartita chose the same texts. In principle, the hypothetical $X$ collection could have contained Gregory I material only, or both Gregory canons and other materials. The first case can almost certainly excluded for a number of reasons: first, why should the compiler of $T C$ have scattered the canons from his Gregory source over the whole collection? Even if this was the case, one would have to assume that $T C$ existed already in its complete form before it was augmented from $X$; this is at odds with the evidence for an independent transmission of the $T C$ core discussed above. In fact, the assumption that $X$ also contained other material does not solve these problems. On the other hand, the idea that the compiler of Tripartita $A$ drew on a collection very similar to BN lat. 13368, namely the collection I label the 'complete $T C$ ', offers an elegant solution without introducing a hypothetical source $X$ which would in any case be largely indistinguishable from $T C$.

Indeed there is further evidence suggesting that Tripartita $A$ depends on $T C$. Firstly, $T C$ was used not only for Gregory I material but apparently also for a wider range of material at an early stage of the compilation of Triparti$t a$, as may be seen in the Clement I section of some manuscripts ${ }^{50}$ ). Secondly,

${ }^{49}$ ) The formal source of c. 29 is obscure; c. 32 is found in the very form and attributed to Gregory I in London, BL Cotton Cleopatra C.VIII, fol. 107v. This manuscript also contains the Collectio Brugensis which was used for the Tripartita A, cf. Brett, Urban II (n. 43), 40-1.

${ }^{50}$ ) This complex question cannot be answered here; I intend to discuss the relation between both collections and the Bruges collection in my PhD thesis. Four manuscripts of the 'first version' contain a set of 'additional' Clement I canons, namely Berlin, SPKB Hamilton 345, Cambridge, Gonville \& Caius College 393 (455), Paris, BN lat. 4282 and Paris, BN lat. 3858. These canons combine fragments from the Bruges collection and $T C$ and in my view represent the most archaic version of Tripartita $A$. As they are not in the Pseudo-Isidorian sequence and largely overlap with other canons of the same section (taken from a long version of Pseudo-Isidore), most were 
the second of the so-called sententiae sections also employed $T C$ for several canons ${ }^{51}$ ). Finally, the structure of Tripartita A1.55 supports the claim that the order of canons is largely determined by the formal sources. The first 21 canons in Tripartita A1.55 are mostly taken from the Collectio Sinemurien$\left.s i{ }^{52}\right)$; cc. 22-81 were almost all taken from $T C$; while the formal source, or sources, of cc. 82-112 remain obscure, it is clear that it was neither the Sinemuriensis nor $T C$. So $T C$ not only tells us about the sources employed for Tripartita $A$ but also shows the method of compilation.

I conclude that for its Gregory I section, Tripartita A picked the 57 Gregory I fragments he found scattered over the $T C$ he used, occasionally rearranging them, but largely preserving the $T C$ sequence. The texts were taken not only from the 'core' of $T C$ but rather from the complete $T C^{53}$ ); three canons (Tripartita A1.55, cc. 29 and 31-2) were integrated in the series from other sources. The Quadripartitus excerpts, on the other hand, were most probably not present in the $T C$ version used here. The compiler of Tripartita $A \operatorname{did}$ not use a Gregory I canon found in this part of $T C$, and he also ignored the whole set of TC Quadripartitus canons ${ }^{54}$ ). This is significant, since he certainly did exploit book four of the Quadripartitus to supplement the Pseudo-Isidorian material of the Tripartita A. Yet this augmentation shows no influence of the $T C$ tradition $^{55}$ ); presumably the Quadripartitus was used directly, as Franz Kerff suggested ${ }^{56}$ ).

later dropped. For the role of the Bruges collection cf. Brett, Urban II (n. 43), 39-40; his provisional edition of the Tripartita will hopefully be available online soon.

$\left.{ }^{51}\right)$ The second sententiae section at the end of Tripartita A (= Tripartita A2.50) contains two blocks of canons which seem to draw on TC: Tripartita A2.50, cc. 13-9=TC, cc. 147 (second part), 151-2, 165 and 194, and Tripartita A2.50, cc. 26-8 = TC, cc. 29 and 154-8. The parallels to $T C, \mathrm{cc} .271$ and 303 , on the contrary, are presumably insignificant and due to a common source, book four of the Quadripartitus. The first sententiae section (Tripartita A2.14) also contains Quadripartitus excerpts, some of which are also found in TC. However, both collection employ the Quadripartitus differently.

$\left.{ }^{52}\right)$ Fowler-Magerl, Fine distinctions (n. 10), 173.

${ }^{53}$ ) Against Fow ler-Magerl (ibid.). Indeed the Tripartita compiler used all Gregory I canons found in the first part of TC: TC, cc. 11-2 (= Tripartita A1.55, cc. 27-8), 26 (c. 26), 42 (c. 33), 67-9 (cc. 34-6), 103-6 (cc. 22-5) and 113-4 (cc. 137-8).

${ }^{54}$ ) There is only one Gregory canon in the Quadripartitus excerpts (TC, c. 245); it was copied into Tarraconensis II (vi, c. 250) which used the 'augmented $T C$ ', for which see below.

${ }^{55}$ ) TC and Tripartita share only two Quadripartitus canons, TC, cc. 271 (= Tripartita A2.50, c. 9) and 303 (c. 1). Tripartita A2.50, cc. 1-12 are all from the Quadripartitus and obviously an independent selection.

${ }^{56}$ ) Kerff, Quadripartitus (n. 10), 74. 
As the Tripartita is attributed to Ivo of Chartres, one could ask whether TC was also used in his other canonistic works. Indeed there is some evidence that the complete $T C$ may have been quoted by Ivo in his letters ${ }^{57}$ ). $T C$ may also have been used for the Decretum but was almost certainly not used for the Panormia ${ }^{58}$ ). However, the relation between Ivo's letters, his Decretum and $T C$ is more complicated and cannot be discussed here ${ }^{59}$ ).

Another late-eleventh century collection that has several canons in common with $T C$, and is possibly related to it, is the Collection in nine books extant in two manuscripts now preserved at Wolfenbüttel and Ghent $\left.{ }^{60}\right)$. The collection is also known as the Collection de Thérouanne, for it has been claimed to have originated there ${ }^{61}$ ), or as the Collectio Sangermanensis IX voluminorum, since the Wolfenbüttel manuscript comes from St-Germain-des-Présand the preface describes the sections as volumina, not libri ${ }^{62}$ ). For the sake of convenience, I retain the more common title Collection in nine books $(9 L)$.

${ }^{57}$ ) Ivo of Chartres, ep. 8 (Yves de Chartres, Correspondance, ed. Jean Leclercq, Paris 1949, 28) quotes the relatively rare Hereticum esse constat ...' discussed above in the very same form as $T C$, c. 129c (BN lat. 13368, fol. 14rb). In epp. 119, 220 and 241 Ivo alludes to statuta maiorum according to which ecclesiastical courts ought not to hear causae, quae legibus non continentur. As Rolf Sprandel, Ivo von Chartres und die moderne Doktrin "Nulla poena sine lege", ZRG 78 Kan. Abt. 47 (1961), 95-108, 98 noted, no such canon can be found in Decretum or Panormia. Indeed no major canon law collection before Ivo has it, in particular not the Tripartita. S prandel assumed that Ivo knew the phrase from secular legislation (ibid., 99). TC, c. 88a (BN lat. 13368, fol. 12ra), however, has a text with almost the same wording as Ivo's letters (Nullae causae a iudicibus ecclesiasticis audiantur, quae legibus non continentur vel prohibite esse noscuntur.), and presents itself as Ivo's formal source.

${ }^{58}$ ) Decretum xvi, cc. 194-205 equals the Sententia Pauli excerpts of TC, cc. 2-8; Decretum ii contains a number of $T C$ canons not found in the known sources of the Decretum; the misattribution in Decretum i, c. 305, finally, could be explained by use of TC, c. 38-9. However, whether there is a direct relation, and if so, in which direction, is not clear. Fowler-Mager1, Fine distinctions (n. 10), 181, n. 66 suggested a dependence of $T C$, cc. 2-8 on Decretum xvi, cc. 194-205; a common source seems not unlikely to me.

${ }^{59}$ ) I hope to give a fuller account of this problem in my $\mathrm{PhD}$ thesis on the canon law in Ivo's letter collection.

${ }^{60}$ ) Wolfenbüttel, Herzog-August-Bibliothek, Gud. lat. 212, and Gent, UB 23. Cf. Max Sdralek, Wolfenbüttler Fragmente (Münster 1891); Laurent Waelkens/ Dirk van den Auweele, La collection de Thérouanne en IX livres à l'abbaye de Saint-Pierre-au-Mont-Blandin: le Codex Gandavensis 235, Sacris erudiri 24 (1980), 115-53; Kéry, Canonical collections (n. 1), 262-3; Fowler-Mager1, Selection (n. 3), 146-8.

${ }^{61)}$ Waelkens/van den Auweele, Collection de Thérouanne, 116-7.

$\left.{ }^{62}\right)$ Fowler-Mager1, Selection, 146. 
Where and when exactly $9 L$ was compiled is unknown. Its sources suggest that $9 L$ originated in Northern France not before the close of the eleventh century. The collection depends on the Collectio Atrebatensis, a Burchard derivative whose place and date of composition are uncertain ${ }^{63}$ ). In the extant manuscript of the Atrebatensis, canons are marked with marginal letters ' $a$ ' to ' $i$ ' indicating the volume of $9 L$ the respective canons were to be copied into $^{64}$ ). The last volume also contains decrees from Clermont 1095, the most recent texts of $9 L^{65}$ ). For this reason it has been suggested that the first eight volumina were compiled prior to the last volumen and indeed prior to Clermont $\left.{ }^{66}\right)$. It has further been suggested that John of Warneton compiled the $9 L^{67}$ ); this is by no means impossible, but there is no convincing evidence in favour of this assumption. Unfortunately, as with the formal sources of $9 L$, the collections depending on it defy an absolute dating. $9 L$ is an important source for the twelfth-century Collectio decem partium, which is modelled on the Panormia. The Collectio decem partium was completed some time after $1124^{68}$ ); a first version may or may not have been begun considerably earlier than this date $\left.{ }^{69}\right)$. Further, $9 L$ may have been used for the collection in

${ }^{63}$ ) On the collection, extant in a single manuscript (Arras, BM 425), cf. Kéry, Canonical collections, 279, and Fowler-Mager1, Selection, 144-5.

$\left.{ }^{64}\right) \mathrm{Cf}$. the concordance table in Waelkens/van den Auweele, Collection de Thérouanne, $140-50$.

${ }^{65}$ ) Canons from the Roman synod of 1099 are found in the Wolfenbüttel manuscript, but not as part of the collection; in the Ghent copy they are integrated into the ninth volumen (Fowler-Magerl, Fine distinctions, 183).

$\left.{ }^{66}\right)$ Waelkens/van den Auweele, Collection de Thérouanne, 131-2.

${ }^{67}$ ) This was first suggested by Sdralek, Wolfenbüttler Fragmente, 59-64, and asserted by Jean Marie de Smet, De heilige Jan van Waasten en de Gregoriaansche hervorming in het bisdom Terwaan (Mémoire de licence, Louvain 1943), cf. A1phonse van Hove, Prolegomena (Mechelen 1945), 333, n. 8; cf. also Waelkens/ van den Auweele, Collection de Thérouanne, 119.

${ }^{68}$ ) Cf. Fournier/Le Bras, Histoire (n. 2), ii, 298 (collection) and Bernard Ja cqueline, Saint Bernard et le droit romaine: à propos d'une citation du "Tractatus de gradibus humilitatis", Nouvelle revue historique de droit français et étranger 39 (1952), 223-8, who pointed out the quotations from Bernard's De gradibus humilitatis (ca. 1124). These texts are an integral part of the collection, not only the manuscripts known to Jacqueline, as are the canons of Lateran I (1123). The fragmentary BN lat. 14145, on which see the next note, does not contain either text.

${ }^{69}$ ) BN lat. 14145 contains a fragment of the Collectio decem partium (10P) consisting of the Ivonian Prologus (with a loss of one folio after fol. 11), a capitulatio of the first nine parts of $10 P$, and one folio with the first four $10 P$ canons, which are all taken from the Panormia; the last text ends in mid-canon at the end of the verso of a leaf. There is evidence that the lost $10 P$ version contained in $\mathrm{BN}$ lat. 14145 was 
Cambridge, CCC 442 which unfortunately cannot be dated with any degree of certainty either ${ }^{70}$ ). Contrary to what has been thought, $9 L$ does not depend on the Tripartita, as Martin Brett discovered ${ }^{71}$ ). Fowler-Magerl suggested that similarities between both collections are due to the fact that both draw on $T C^{72}$ ). She also pointed out that $9 L$ and $T C$ share some very rare material, especially the famous dictum 'Hereticum esse constat, qui non concordat Romanae ecclesiae' discussed above ${ }^{73}$ ).

As the systematic $9 L$ rearranges the canons taken from non-systematic sources completely, the use of $T C$ is not easy to determine. There are some forty canons both collections have in common where I assume that the employment of $T C$ for $9 L$ is the most likely explanation ${ }^{74}$ ). At least in one case,

archaic. It did not, however, only contain Panormia material, as the capitulatio already refers to pars four which contains material taken from elsewhere. Compared to the other manuscripts, BN lat. 14145 lacks the second preface and part ten, a penitential book; further, the capitulatio does not refer to the decrees of Poitiers 1100 and Poitiers 1119. This, however, does not necessarily mean that BN lat. 14145 was compiled before 1100 (against Fowler-Magerl, Selection, 149). The terminus post quem is the compilation of the Panormia which was compiled some time after the Decretum (ca. 1095) but may be considerably later than this date.

${ }^{70}$ ) Cf. ibid., 147 against Brett, The Collectio Lanfranci and its competitors, in: Intellectual life in the Middle Ages: essays presented to Margaret Gibson, ed. Le sley Smith/Benedicta Ward (London 1992), 157-74, 169-70. The point of issue between them is whether the Cambridge collection depends entirely on the $9 L$, rather than that of Arras.

$\left.{ }^{71}\right)$ Brett, Collectio Lanfranci, 169, n. 47 against Fournier/Le Bras, Histoire, ii, 286.

$\left.{ }^{72}\right)$ Fowler-Magerl, Selection, 147: 'the collection [i.e. TC] was apparently the formal source for both the Collectio A of the Tripartita and for the Sangermanensis.'

$\left.{ }^{73}\right)$ Ibid. The canon $(T C$, c. $129 \mathrm{c})$ is not found in any major canon law collection, but most $T C$-influenced collections (see appendix). Only Anselm of Lucca, Collectio canonum xii, c. 47 has a similar rubric: 'Non esse veram fidem quae cum Romana ecclesia non convenit' (ed. Kathleen Grace Cushing, Papacy and law in the Gregorian revolution: the canonistic work of Anselm of Lucca, Oxford 1998, 188). Cf. Horst Fuhrmann, "Quod catholicus non habeatur, qui non concordat Romanae ecclesiae": Randnotizen zum Dictatus Papae, in: Festschrift für Helmut Beumann zum 65. Geburtstag, ed. Kurt-Ulrich Jäschke/Reinhard Wenskus (Sigmaringen 1977), 263-87.

$\left.{ }^{74}\right) T C$, cc. 9 (=9L ii, c. 264), 23 (vi, v. 49), 26 (vi, c. 8), 28 (iii, c. 40), 31 (vii, c. 101), 43 (iii, c. 122), 53 (1, c. 129), 71a (iv, c. 36), 76 (v, c. 172), 79b (v, c. 13 ), 83 (v, c. 56), 90 b (v, c. 91), 95 (v, c. 123), 115 (i, c. 37), 125 (iv, c. 37), 129 c (vii, c. 69), 139 (iv, c. 1), 141 (i, c. 8), 144 (ii, c. 279), 146b (iv, c. 35), 156 (vii, c. 78), 159c (ii, c. 276), 167a-b (ii, c. 290-1), 170 (iii, c. 112), 182 (i, c. 103), 186 (i, c. 113), 215a (viii, c. 15), 225 (v, c. 158), 226 (iii, c. 87), 229 (v, c. 152),

7 Zeitschrift für Rechtsgeschichte. CXXII. Kan. Abt. 
even the extant form of $T C$ in BN lat. 13368 preserves a more precise inscription than $9 L^{75}$ ). Parallels between both collections are limited to the first eight volumina of $9 L^{76}$ ). This supports the idea that the last volumen originated independently of the first eight books and possibly later than these; it also makes only scant use of the Atrebatensis ${ }^{77}$ ). The compiler of $9 L$ seemingly used a form of $T C$ which did not yet contain the Sententiae Pauli. But whether he used the 'complete' or the 'augmented' form of TC is hard to tell.

The manuscript Palermo, Archivio della Cattedrale, 14 is best known as one of the five copies of the Abbreviatio Ansegisi et Benedicti Levitae ${ }^{78}$ ). It also contains most of the other miscellaneous material commonly transmitted with the Abbreviatio: councils taken from the Dionysio-Hadriana, canons from the Dacheriana, excerpts from the Hibernensis, excerpts from the council of Meaux, the so-called Collectio 342 capitulorum, and the so-called Collectio 114 capitulorum $^{79}$ ). It shares a synodal order with two of the Paris

230 (ii, c. 267), 234a-b (ii, c. 265-6), 263 (iii, c. 43), 274 (v, c. 26) and 277 (ii, c. 19). $9 L$ contains in volume six, c. 16 , the Decretum Gelasianum also found at the beginning of $T C$, but there is no cogent evidence that $9 L$ depends on $T C$ here.

${ }^{75}$ ) TC, cc. 234a: Augustinus in sermone de verbis evangelii, cap. 10, and 234b: Idem in eodem, cap. 28; $9 \mathrm{~L}$ ii, cc. 265-6 have the inscription Augustinus in sermone de verbis domini and item idem in eodem, respectively. Cf. also Decretum ii, 102-4.

${ }^{76}$ ) The only exception is $9 L \mathrm{ix}, \mathrm{c} .16=T C$, c. 27 , but this canon could have reached $9 L$ from many sources.

${ }^{77}$ ) According to Waelkens/van den Auweele, Collection de Thérouanne (n. 60 ), 144, only one canon in the Atrebatensis was marked with an 'i' (and accordingly copied into $9 L$ ).

${ }^{78}$ ) The manuscript was first discussed in Enrico Besta, Di una collezione canonistica Palermitana, Circolo giuridico 40 (1909), 8-21; on the Abbreviatio cf. Emil Seckel, Benedictus Levita decurtatus et excerptus: eine Studie zu den Handschriften der falschen Kapitularien, in: Festschrift für Heinrich Brunner: zum 50-jährigen Doktorjubiläum am 8. April 1914 überreicht von der Juristenfakultät der Universität Berlin (Munich 1914), 377-464 and Gerhard S chmitz, Die Überlieferung der sog. "Abbreviatio Ansegisi et Benedicti Levitae": mit einem Anhang: die Abbreviatiound Dacheriana-Rezeption in der 17-Bücher-Sammlung, Deutsches Archiv für Erforschung des Mittelalters 40 (1984), 176-99. The manuscript is sometimes erroneously referred to as '2 Qq E 17'.

${ }^{79}$ ) Cf. Fournier, Notice sur le manuscrit H. 137 de l'École de Médecine de Montpellier, Annales de l'Université de Grenoble 9 (1897), 357-89, Jacqueline Rambaud-Buhot, Un corpus inédit de droit canonique, in: Humanisme actif: mélanges d'art et de littérature offerts à Julien Cain (Paris 1968), ii, 271-81 and the corrections of Hubert Mordek, Kirchenrecht und Reform im Frankenreich: die Collectio Vetus Gallica, die älteste systematische Kanonessammlung des fränkischen Gallien: Studien und Edition (Berlin 1975), 180-2. 
manuscripts of the Abbreviatio; with the Montpellier manuscript it shares some of Fulbert's letters and his penitential ${ }^{80}$ ). The first two letters of Fulbert in the Palermo manuscript are not contained in the Montpellier copy, but the others are, and the sequence is exactly the same ${ }^{81}$ ). The Abbreviatio itself in the Palermo manuscript shares a common archetype with the three Paris copies but is closest to $\mathrm{BN}$ lat. $3889 \mathrm{~A}^{82}$ ).

In addition, the Palermo codex contains a set of 61 canons taken from TC. Fournier-Le Bras, who did not know BN lat. 13368, labelled these excerpts Italian on grounds that they allegedly formed a 'Gregorian reform collection'83). However, the manuscript is most probably French and all its other sources point to Northern France; both the Abbreviatio and TC enjoyed considerable circulation in France but had no known influence in Italy. The Palermo excerpts are taken from the complete $T C$ and faithfully preserve the order of the formal source ${ }^{84}$ ). The selection coincides often but not always with that of the Tarraconensis II. Palermo begins the excerpts with the Decretum Gelasianum which is also the first canon in $T C$ and continues with $T C$, cc. 9, 10, 12-4; this makes it likely that the Sententiae Pauli (cc. 2-8 in the extant BN lat. 13368) were not yet part of the $T C$ employed here. By the same token, the excerpts end with $T C$, c. 234 and there is no evidence that the formal source of Palermo contained any of the canons found only in the 'augmented' form (i.e. TC, cc. 241-338). Therefore I conclude that the complete form of $T C$, not the augmented, was employed here.

The collections discussed above as drawing on the complete form of TC

$\left.{ }^{80}\right)$ Cf. Herbert Schneider, Die Konzilsordines des Früh- und Hochmittelalters (Hanover 1996), 162 (manuscript) and 176-86 (edition of Ordo 2); Frederick Behrends, Introduction, in: The letters and poems of Fulbert of Chartres, ed. idem (Oxford 1976), xiii-xc, xlv-xlvi (letters); Kerff, Das sogenannte Paenitentiale Fulberti: Überlieferung, Verfasserfrage, Edition, ZRG 116 Kan. Abt. 73 (1987), 1-40 (penitential). Cf. also Mordek, Bibliotheca capitularium regum Francorum manuscripta: Überlieferung und Traditionszusammenhang der fränkischen Herrschererlasse (Munich 1995) (manuscripts).

${ }^{81}$ ) Palermo, Archivio della Cattedrale 14, foll. 157v-159v contains epp. 123, 29, 4, 14, 8, 7 and 11 (ed. Behrends).

${ }^{82}$ ) Schmitz, Abbreviatio Ansegisi (n. 78), 188-9.

${ }^{83}$ ) Fournier/Le Bras, Histoire (n. 2), ii, 150-1, repeated in Kéry, Canonical collections (n. 1), 277.

${ }^{84}$ ) Palermo, Archivio della Cattedrale 14, foll. $131 \mathrm{r}-147 \mathrm{r}$ contains in this order $T C$, cc. 1, 9-10, 12-4, 17, 29-30, 34-5, 38, 39 (second part only), 42, 40 (sic), 45, 47, 49, 54-5, 57, 59-60, 61 (first part), 77-8, 79 (first part), 81, 86, 101 (first part), 125, 127-30, 132, 134, 138-42, 146, 147 (second part), 149-52, 154, 159, 192-3, 196-7, 210, 231-3 and 234 (first part). 
all originated in Northern France between the end of the eleventh century and the beginning of the twelfth; as it seems, TC circulated widely in this region around 1100 . It was presumably there that it was augmented with excerpts taken from book four of the Quadripartitus. This augmented form, to which we must now turn, was used by the Tarraconensis II, and for an appendix added to a copy of the Caesaraugustana II.

The Liber Tarraconensis is a non-systematic collection of the late eleventh century traditionally associated with Poitiers ${ }^{85}$ ). Some time after 1097 the collection was augmented with additional material at the beginning and the end and divided into seven books to form the so-called Tarraconensis $I I^{86}$ ). The two extant copies come from Southern France and Catalonia respectively, and it is not unlikely that the reworked version originated there ${ }^{87}$ ). TC was used for the material added at the end of the collection which now forms the second part of book six; in total, the compiler chose 148 canons or almost half of the augmented $T C^{88}$ ). Augmenting an existing collection, he omitted those $T C$ canons already contained in the first version of the Tarraconensis $\left.{ }^{89}\right)$. The first text in TC, the Decretum Gelasianum, was conceivably omitted for this rea$\left.\operatorname{son}^{90}\right)$. The borrowing extends from the very beginning to the very end of the augmented $T C$, beginning with $T C$, cc. 9-14, the first canons after the Decretum Gelasianum and the Sententiae Pauli, and ending with TC, cc. 293-304,

${ }^{85}$ ) Cf. Fowler-Mager1, Selection (n. 3), 74-6, and Kéry, Canonical collections, 204-5.

$\left.{ }^{86}\right)$ Cf. Paul Fournier, Le Liber Tarraconensis: étude sur une collection canonique du $\mathrm{XI}^{\mathrm{e}}$ siècle, in: Mélanges Julien Havet: recueil de travaux d'érudition dédiés à la mémoire de Julien Havet (1853-1893) (Paris 1895), 259-81; Fowler-Mag er1, Selection, 105-6.

$\left.{ }^{87}\right)$ Fowler-Mager1, Selection, 105.

${ }^{88}$ ) TC, cc. 9-14 (= Tarraconensis II vi, cc. 118-23), 17 (c. 124), 19-20 (c. 125-6), 22 (c. 127), 25 (c. 129), 29 (c. 130), 34-6 (cc. 131-3), 39-43 (cc. 134-9), 46-9 (cc. 140-3), 54 (c. 144), 59 (c. 145), 66-9 (c. 146-9), 71 (c. 150), 73 (c. 151), 85 (c. 152), 88 (c. 153-4), 90b (c. 155), 99 (c. 156), 103-4 (c. 157-8), 109 (c. 159), 113b (c. 160), 118-22 (c. 161-5), 126 (c. 166), 128-32 (cc. 167-71), 134-9 (cc. 172-5), 141-6a (cc. 176-81), 147-54 (cc. 182-91), 156-8 (c. 192a-c), 159b-c (c. 193a-b), 161-5 (cc. 194-8), 167-73 (cc. 199-205), 175-9 (cc. 206-10), 181-2 (cc. 211-2), 184-8 (cc. 213-7), 191-8 (cc. 218-25), 203 (c. 226), 207-14 (cc. 227-34), 217 (c. 235), 222-8 (cc. 236-41c), 231-5 (cc. 242-7), 238-9 (cc. 248-9), 245 (c. 250), 247-8 (cc. 251-2), 260-1 (cc. 253-4), 292-303 (cc. 255-66). (Corrected from Fowler-Mager1, Fine distinctions, 181, n. 66.)

$\left.{ }^{89}\right)$ E.g. TC, cc. 222-32 = Tarraconensis II vi, cc. 236-43, with the sole exception of $T C$, c. 229 which was already contained in Tarraconensis I iv, c. 33.

${ }^{90}$ ) It was already found in Tarraconensis I i, c. 236. 
the last canons of the Quadripartitus excerpts and thus the augmented TC. This makes it almost certain that $T C$, cc. 2-8 and cc. 304-38 were not part of the $T C$ version used for the Tarraconensis II; these canons were added to $T C$ only at a very late stage of the transmission. Apart from that, the formal source of the Tarraconensis II must have been very similar to BN lat. $13368^{91}$ ).

Another collection that was possibly augmented from $T C$ is the Collectio Caesaraugustana. The first version of this collection (Caesaraugustana I) originated in Southern France or Catalonia presumably in the first half of the twelfth century ${ }^{92}$ ). Its most recent text is from 1108 (JL 6613), but the exact terminus ad quem is controversial ${ }^{93}$ ). The Caesaraugustana I depends on several pre-Gratian collections including those of Anselm of Lucca, Deusdedit and two of the Ivonian collections, the Tripartita and the Decretum ${ }^{94}$ ); Brett recently suggested that it depends on the Arsenal collection, a preparatory collection of the Ivonian Decretum ${ }^{95}$ ). It also contains a forged letter attributed to Leo I ( JK †446) which rejects the claims of Narbonne to primacy in Catalonia; this suggests that it was intended for use there ${ }^{96}$ ). The provenance of the two extant manuscripts supports this idea ${ }^{97}$ ).

In the 1140s, the Caesaraugustana I was reworked; new canons were added partly from the sources used for the first version, partly from other sources, including $T C$ according to Fowler-Mager ${ }^{98}$ ). This second ver-

$\left.{ }^{91}\right)$ The first part of book six (cc. 1-117) draws on other sources; in the second part, only one canon (Tarraconensis II vi, c. 128) has no parallel in the extant BN lat. 13368; one could reasonably suspect that it was part of the $T C$ version used for the Tarraconensis II.

${ }^{92}$ ) Fournier, La collection canonique dite Caesaraugustana, Nouvelle revue historique de droit français et étranger 45 (1921), 53-79; Brett, The sources and influence of Paris, Bibliothèque de l'Arsenal 713, in: Proceedings 9 (n. 36), 149-67, 164-7; cf. Kéry (n. 1), 260-2 for further references.

$\left.{ }^{93}\right)$ Cf. André Gouron, La science juridique française aux $\mathrm{XI}^{\mathrm{e}}$ et $\mathrm{XII}^{\mathrm{e}}$ siècles: diffusion du droit de Justinien et influences canoniques jusqu'à Gratien (Milan 1978), $70-1$.

${ }^{94}$ ) Fowler-Magerl, Selection, 179-80. For the controversial relation between Caesaraugustana and Polycarp see also Uwe Horst, Die Kanonessammlung Polycarpus des Gregor von S. Grisogono: Quellen und Tendenzen (Munich 1980).

${ }^{95}$ ) Brett, Sources and influence, 160-7.

${ }^{96}$ ) Fowler-Magerl, Selection, 179; the letter is edited in MGH. Epp. 3, 91

${ }^{97}$ ) The two copies are Salamanca, Universidad Civil 2644 (from Saragossa) and the incomplete Paris, BN lat. 3875 from St Maria in Ripoll, Catalonia. For the manuscripts and further references cf. Kéry, Canonical collections, 260-2.

${ }^{98}$ ) Fowler-Magerl, Selection, 182: 'Many of the canons added to the first version came from the same sources used for the first version, others from Poitevine 
sion (Caesaraugustana II) is not divided into books, although its model probably was; nonetheless, it is a systematic collection. This makes it more difficult to determine the relation to an unsystematic collection like $T C$, as the order of canons provides little if any evidence. Given that Caesaraugustana II still remains to be analysed, great caution is necessary before parallels to another collection can be taken as evidence for the influence of the latter. Indeed the case of the Caesaraugustana II is even more complicated, as the first version had already drawn heavily on Tripartita A, which certainly drew on $T C$. At the present I cannot affirm that the Caesaraugustana II drew on TC directly ${ }^{99}$ ). More evident, however, is the direct use of $T C$ for the appendix to the Caesaraugustana II in BN ms lat. $3876^{100}$ ). The appendix contains 308 canons about 60 of which are also in $T C$; there are several series of canons preserving the order of $T C^{101}$ ). The canons are taken from the whole range of $T C$, and a series extending to the Quadripartitus excerpts suggests that an augmented $T C$ was employed here ${ }^{102}$ ). It seems that the compiler of the appendix, like the compiler of Tarraconensis II, avoided TC canons already found in the Caesaraugustana II he was supplementing.

As sketched above, the compilation of $T C$ was not a very sophisticated enterprise; basically, four large blocks of excerpts from different sources were placed end to end over a period of some time. The unsystematic collections and excerpts drawing on TC confirm that the extant version in BN lat. 13368 preserves the structure of the collection relatively well, although it seems to

collections such as the second version of the Tarraconensis and the collection in the Ms Paris BN lat. 13368.'

${ }^{99}$ ) In discussion, Dr Fowler-Magerl did no longer insist on $T C$ as a formal source of the second Caesaraugustana. For a detailled analysis of this collection see her The version of the Collectio Caesaraugustana in Barcelona, Archiv de la Corona de Aragón, MS San Cugat, in: Ritual, text and law, studies ... presented to Roger E. Reynolds, ed. Richard F. Gryng/Cushing (Aldershot 2004), 269-80.

$\left.{ }^{100}\right)$ For the manuscript cf. Fournier/Le Bras, Histoire, ii, 270-2, and FowlerMagerl, Vier französische und spanische vorgratianische Kanonessammlungen, in: Aspekte europäischer Rechtsgeschichte: Festgabe für H. Coing zum 70. Geburtstag, ed. Christoph Bergfeld (Frankfurt am Main 1982), 123-46, 144-6.

${ }^{101)}$ E.g. BN lat. 3876 , cc. $24-30=T C$, cc. $73,75,80,88 \mathrm{a}, 88 \mathrm{~b}, 90 \mathrm{a}$ and 90 d. See the appendix.

$\left.{ }^{102}\right)$ BN lat. 3876 , cc. $68-9(=T C$, c. $230-1), 70$ (c. 239$), 71$ (c. 255), $72-3$ (c. 266-7), 75 (c. 273), 77 (c. 279), 79-80 (c. 294-5) and 82 (c. 297) or BN lat. 3876, cc. 51 (c. 155a), 52 (c.156), 53 (c. 181), 54 (c. 233) and 55-6 (c. 234). For reasons I was not able to eludicate, BN lat. 3876 erroneously attributes all canons of the latter series to Isidore. 
contain some idiosyncratic additions. On the other hand, there are only a few canons which can be inferred to have been in the archetypical $T C$ from their appearance in other versions but are not in BN lat. 13368.

The core of TC (cc. 126-96 of the extant form in BN lat. 13368) was used for three related excerpts after ca. 1075 and later the Appendix Seguntina. This core was then supplemented at the beginning (cc. 1 and 9-124) and the end (cc. 197-240) with supplements compiled not before 1059. This version, the complete $T C$, was used for Tripartita $A$ in the 1090s; it was further used for the Collection in nine books and the Palermo excerpts at about the same time and may well have been known to Ivo of Chartres. While some canons in the core seem to have been displaced, the complete version had the order of the extant form in BN lat. $13368^{103}$ ). When exactly the cc. $2-8$ were added to $T C$ is hard to decide; as mentioned above, there may have been a common Chartrain source for $T C$ and the Decretum attributed to Ivo of Chartres. This idea is supported by the presence of the Sententiae Pauli excerpts in Decretum xvi and a lost manuscript from Chartres which seems to have predated both $T C$ and the Ivonian Decretum ${ }^{104}$ ). As the complete $T C$, book four of the Quadripartitus and the idiosyncratic Sententiae Pauli excerpts were all known at Chartres, it is not impossible that the augmented form of TC originated at Chartres or under Chartrain influence. In any case, the augmented form with the Quadripartitus excerpts (cc. 241-338) was in the twelfth century used for the appendix to the Caesaraugustana II in BN lat. 3876 and book six of the Tarraconensis II; if the Sententiae Pauli were present in the formal source of these two collections, they were not used. Finally, BN lat. 13368 is a near-complete copy of $T C$ with all additions (including cc. 2-8) of the mid-twelfth century.

The history of $T C$ shows how influential minor unsystematic collections

${ }^{103}$ ) The Palermo excerpts (cc. 56-8) show that $T C$, cc. 154-8 were already in the order of BN lat. 13368, and not displaced as in the collections drawing on the $T C$ 'core'.

${ }^{104}$ ) Chartres, BM 193 (olim 172) seems to have contained the very same texts. The manuscript was destroyed in 1944, but according to the Catalogue général xi (1890), 99-100, the ms contained on foll. 5r-5v Roman law under the heading De lege Theodosiana Pauli with the incipit Si inter aliquos conveniat. Inscription, incipit and lenghth match the Sententiae Pauli series in Decretum xvi and BN lat. 13368. My thanks are to Dr Brett, who kindly put at my disposal his reconstruction of the content of Chartres, BM 193. Cf. also Johann Friedrich Schulte, Iter Gallicum, Sitzungsberichte der Österreichischen Akademie der Wissenschaften in Wien, Philosophisch-Historische Klasse 59/4 (1868), 355-496, 460-6 and the facsimile in his appendix. 
could be in the eleventh and twelfth centuries. $T C$ itself is primitive; yet it contained enough interesting material, and was short enough, to be copied frequently. Its influence seems to have been wider than that of several betterknown collections. Yet I do not argue that $T C$ is an important collection, only mistakenly classified as a minor florilegium. Rather, the interesting aspect of $T C$ lies precisely in the fact that it is an ordinary 'minor' collection, the influence of which would probably never have been recognised if BN lat. 13368 had not survived or had continued to escape the attention of modern scholars. This implies that potentially many collections like $T C$ could once have existed or may yet be discovered. $T C$ thus reminds us how very limited is our knowledge of the complex history of pre-Gratian canon law collections. The wide circulation $T C$ seemingly enjoyed ca. 1050 to ca. 1150 in widely scattered centres also warns against the idea that shared material necessarily implies common origin in time and space. It further warns against assuming that collections were compiled soon after the most recent material they contain. The latest dated material in $T C$ comes from ca. 1075, but although $T C$ was added to several times and remained in use until at least the $1140 \mathrm{~s}$, no more recent material was added.

\section{Appendix: A concordance of canonical collections related to $T C$}

Where applicable, the numbering of the canons in the following concordance table is taken from the Kanones $J$ database (see above note 5) unless otherwise noted. An ' $x$ ' after a canon indicates a variant form of a canon. Small letters (e.g. TC, cc. 153a and 153b) indicate subdivisions of the canons not indicated in the manuscripts. Digital numbers (e.g. TC, c. 39.1) indicate a textual division by 'item' or the like in mid-canon. Capital letters (e.g. TC, cc. 211A and 211B) specify interpolated canons. These were presumably present in the $T C$ version current in the late eleventh century but dropped later; the canons, lacking in $\mathrm{BN}$ lat. 13368, were interpolated from the related manuscripts as discussed above.

Quad. iv Book four of the Quadripartitus, the main source of the additions of the 'augmented TC'.

13368 The collection in Paris, BN lat. 13368, foll. $9^{v}-20^{v}$. The division of canons and the numbering is taken from the Kanones database, although I have silently emended some errors (e.g. the supposed absence of c. 174.2 from BN lat. 13368).

14193 The collection in Paris, BN lat. 14193, foll. 87v $-94^{\mathrm{v}}$.

13413 The collection in Paris, BN lat. 13413, foll. $122^{\mathrm{r}}-152^{\mathrm{r}}$.

Antwerp The collection in Antwerp, Plantin-Moretus M.82, foll. $95^{\mathrm{v}}-100^{\mathrm{r}}$.

App. Seg. The Appendix Seguntina to the Panormia. 
Palermo The excerpts in Palermo, Archivio della Cattedrale 14, foll. 131 $1^{\mathrm{r}}-147^{\mathrm{v}}$, taken solely from $T C$.

Trip. The Gregory I section in Tripartita A1.55; parallels to other parts of the Tripartita are not uncommon. The numbering is based on that of the forthcoming edition by Brett, a provisional version of which will hopefully be available online soon.

Tarra. vi Book six of the Tarraconensis II; parallels of the first Tarraconensis to $T C$ are given in brackets.

3876 The appendix to the Caesaraugustana II in Paris, BN lat. 3876, foll. $117^{\mathrm{v}}-136^{\mathrm{v}}$.

\begin{tabular}{|c|c|c|c|c|c|c|c|c|c|}
\hline Quad. iv & 13368 & 14193 & 13413 & Antwerp & App. Seg. & Palermo & Trip. & Tarra. vi & 3876 \\
\hline \multicolumn{10}{|c|}{ The Decretum Gelasianum, presumably part of the 'complete $T C$ ' } \\
\hline & c. 1 & & & & & c. 1 & & (i, c. 236) & \\
\hline \multicolumn{10}{|c|}{ Excerpts from the Sententiae Pauli, presumably not part of any $T C$ version except that extant in BN lat. 13368} \\
\hline & c. 2 & & & & & & & & \\
\hline & c. 3 & & & & & & & & \\
\hline & c. 4 & & & & & & & & \\
\hline & c. 5 & & & & & & & & \\
\hline & c. 6 & & & & & & & & \\
\hline & c. 7 & & & & & & & & \\
\hline & c. 8 & & & & & & & & \\
\hline \multicolumn{10}{|c|}{ Beginning of of the first set additions forming the 'complete $T C$ ' } \\
\hline & c. 9 & & & & & c. 2 & & c. 118 & \\
\hline & c. 10 & & & & & cc. 3-4 & & c. 119 & \\
\hline & c. 11 & & & & & & c. 27 & c. 120 & \\
\hline & c. 12 & & & & & c. 5 & c. 28 & c. 121 & \\
\hline & c. 13 & & & & & c. 6 & & c. 122 & \\
\hline & c. 14 & & & & & c. 7 & & c. 123 & \\
\hline & c. 15 & & & & & & & & \\
\hline & c. 16 & & & & & & & & \\
\hline & c. 17 & fol. 93r & & & & c. 8 & & c. 124 & c. 22 \\
\hline & c. 18 & & & & & & & & \\
\hline & c. 19 & & & & & & & c. 125 & \\
\hline & c. 20 & & & & & & & c. 126 & \\
\hline & c. 21 & & & & & & & & \\
\hline & c. 22 & & & & & & & c. 127 & \\
\hline & c. $22 \mathrm{~A}$ & & & & & & & c. 128 & \\
\hline & c. 23 & & & & & & & & c. 12 \\
\hline & c. 24 & & & & & & & & \\
\hline & c. 25 & & & & & & & c. 129 & \\
\hline & c. 26 & & fol. $150 \mathrm{vx}$ & & & & c. 26 & (iv, c. 52x) & \\
\hline & c. 27 & & & & & & & & c. 114 \\
\hline & c. 28 & & & & & & & $(\mathrm{v}, \mathrm{c} .43)$ & \\
\hline & c. 29 & & & & & c. 9 & & c. 130 & \\
\hline & c. 30 & & & & & c. 10 & & $(\mathrm{v}, \mathrm{c} .13)$ & \\
\hline & c. 31 & & & & & & & $(\mathrm{v}, \mathrm{c} .14)$ & \\
\hline & c. 32 & & & & & & & & \\
\hline & c. 33 & & & & & & & & \\
\hline & c. 34 & & & & & c. 11 & & c. 131 & \\
\hline & c. 35 & & & & & c. 12 & & c. 132 & \\
\hline
\end{tabular}




\begin{tabular}{|c|c|c|c|c|c|c|c|c|c|}
\hline Quad. iv & 13368 & 14193 & 13413 & Antwerp & App. Seg. & Palermo & Trip. & Tarra. vi & 3876 \\
\hline & c. 36 & & & & & & & c. 133 & \\
\hline & c. 37 & & & & & & & & \\
\hline & c. 38 & & & & & c. 13 & & (v, c. 2) & \\
\hline & c. 39.1 & & & & & & & c. 134 & \\
\hline & c. 39.2 & & & & & c. 14 & & c. 135 & \\
\hline & c. 40 & & & & & c. 16 & & c. 136 & c. 125 \\
\hline & c. 41 & & & & & & & c. 137 & \\
\hline & c. 42 & & & & & c. 15 & c. 33 & c. 138 & \\
\hline & c. 43 & & & & & & & c. 139 & c. 117 \\
\hline & c. 44 & & & & & & & $(\mathrm{v}, \mathrm{c} .53)$ & c. 118 \\
\hline & c. 45 & & & & & c. 17 & & (v, c. 19) & \\
\hline & c. 46 & & & & & & & c. 140 & \\
\hline & c. 47.1 & & & & & c. $18 ?$ & & c. 141.1 & \\
\hline & c. 47.2 & & & & & c. 19 ? & & c. 141.2 & \\
\hline & c. 47.3 & & & & & c. 19 ? & & c. 141.3 & \\
\hline & c. 48 & & & & & & & c. 142 & \\
\hline & c. 49 & & & & & c. 20 & & c. 143 & \\
\hline & c. 50 & & & & & & & & \\
\hline & c. 51 & & & & & & & & \\
\hline & c. 52 & fol. 90r & fol. 124r & & & & & (iii, c. 6) & \\
\hline & c. 53 & & & & & & & & \\
\hline & c. 54 & & & & & c. 21 & & c. 144 & \\
\hline & c. 55 & & & & & c. 22 & & & \\
\hline & c. 56 & & & & & & & & \\
\hline & c. 57 & & & & & c. 23 & & & \\
\hline & c. 58 & & & & & & & (iii, c. 36x) & c. 14 \\
\hline & c. 59 & & & & & cc. $24-5$ & & $\begin{array}{l}\text { c. } 145 \\
\text { (iii, c. 62) }\end{array}$ & c. 16 \\
\hline & c. 60 & & & & & c. 26 & & (iii, c. $38 x$ ) & \\
\hline & c. 61.1 & & & & & c. 27 & & & \\
\hline & c. 61.2 & & & & & & & (i, c. $72 x)$ & \\
\hline & c. 62 & & & & & & & & \\
\hline & c. 63 & & & & & & & & \\
\hline & c. 64 & & & & & & & & \\
\hline & c. 65.1 & & & & & & & (iii, c. $42 x$ ) & \\
\hline & c. 65.2 & & & & & & & & \\
\hline & c. 66 & & & & & & & c. 146 & \\
\hline & c. 67 & & fol. 149r & & & & c. 34 & c. 147 & \\
\hline & c. 68 & & & & & & c. 35 & c. 148 & \\
\hline & c. 69 & & & & & & c. 36 & c. 149 & \\
\hline & c. 70 & & & & & & & & \\
\hline & c. 71.1 & & & & & c. 28 & & c. 150.1 & c. 57 \\
\hline & c. 71.2 & & & & & & & c. $150.2 \mathrm{x}$ & \\
\hline & c. 71.3 & & & & & & & c. $150.3 \mathrm{x}$ & \\
\hline & c. 72 & & & & & & & & \\
\hline & c. 73 & & & & & & & c. 151.1 & c. $24 \mathrm{x}$ \\
\hline & c. $73 \mathrm{~A}$ & & & & & & & c. 151.2 & \\
\hline & c. 74 & & & & & & & & \\
\hline & c. 75 & & & & & & & & c. $25 \mathrm{x}$ \\
\hline & c. 76 & & & & & & & (ii, c. 9x) & \\
\hline & c. 77 & & & & & c. 29 & & (ii, c. 5) & \\
\hline & c. 78 & & & & & c. 30 & & (ii, c. 5) & \\
\hline
\end{tabular}




\begin{tabular}{|c|c|c|c|c|c|c|c|c|c|}
\hline Quad. iv & 13368 & 14193 & 13413 & Antwerp & App.Seg. & Palermo & Trip. & Tarra. vi & 3876 \\
\hline & c. 79.1 & & & & & c. 31 & & & \\
\hline & c. 79.2 & & & & & & & (iii, c. 82) & \\
\hline & c. 80 & & & & & & & & c. 26 \\
\hline & c. 81 & & & & & c. 32 & & (ii, c. 13) & \\
\hline & c. 82 & & & & & & & & \\
\hline & c. 83 & & & & & & & & \\
\hline & c. 84 & & & & & & & (v, c. 63) & \\
\hline & c. 85 & & & & & & & c. 152 & c. 98 \\
\hline & c. 86 & & & & & c. 33 & & & \\
\hline & c. 87 & & & & & & & (ii, c. 66x) & \\
\hline & c. 88.1 & & & & & & & c. 153 & c. 27 \\
\hline & c. 88.2 & & & & & & & c. 154 & c. 28 \\
\hline & c. 89 & & & & & & & & \\
\hline & c. 90.1 & & & & & & & & c. 29 \\
\hline & c. 90.2 & & & & & & & c. 155 & \\
\hline & c. 90.3 & & & & & & & & \\
\hline & c. 90.4 & & & & & & & & \\
\hline & c. 91 & & & & & & & & c. 30 \\
\hline & c. 92 & & & & & & & (iv, c. 41x) & \\
\hline & c. 93 & & & & & & & & \\
\hline & c. 94 & & & & & & & & \\
\hline & c. 95 & & & & & & & & c. 86 \\
\hline & c. 96 & & & & & & & & c. 87 \\
\hline c. 205 & c. 97 & & & & & & & & \\
\hline & c. 98 & & & & & & & (iv, c. 58) & \\
\hline & c. 99 & & & & & & & c. 156 & c. 90 \\
\hline & c. 100 & & & & & & & & \\
\hline & c. 101.1 & & & & & & & & c. 65 \\
\hline & c. 101.2 & & & & & & & & \\
\hline & c. 101.3 & & & & & c. $34 \mathrm{x}$ & & (iv, c. 6) & \\
\hline & c. 102 & & & & & & & & \\
\hline & c. 103 & & & & & & c. 22 & c. 157 & \\
\hline & c. 104 & & & & & & c. 23 & c. 158 & \\
\hline & c. 105 & & & & & & c. 24 & (iii, c. $24 x$ ) & \\
\hline & c. 106 & & & & & & c. 25 & (iv, c. 22) & \\
\hline & c. 107 & & & & & & & & \\
\hline & c. 108.1 & & & & & & & & \\
\hline & c. 108.2 & & & & & & & & \\
\hline & c. 109 & & & & & & & c. 159 & \\
\hline & c. 110 & fol. 93r & & & & & & & \\
\hline & c. 111.1 & fol. 93r & & & & & & & \\
\hline & c. 111.2 & fol. $93 r$ & & & & & & & \\
\hline & c. 112 & & & & & & & & \\
\hline & c. $113 \mathrm{a}$ & & & & & & c. $37 \mathrm{a}$ & & \\
\hline & c. $113 \mathrm{~b}$ & & & & & & c. $37 \mathrm{~b}$ & c. 160 & \\
\hline & c. 114 & & & & & & c. 38 & & \\
\hline c. 213 & c. 115 & & & & & & & & \\
\hline & c. 116 & & & & & & & & c. 85 \\
\hline & c. 117 & & & & & & & & \\
\hline & c. 118 & & & & & & & c. 161 & c. 67 \\
\hline & c. 119 & & & & & & & c. 162 & \\
\hline & c. 120 & & & & & & & c. 164 & \\
\hline
\end{tabular}




\begin{tabular}{|c|c|c|c|c|c|c|c|c|c|}
\hline Quad. iv & 13368 & 14193 & 13413 & Antwerp & App. Seg. & Palermo & Trip. & Tarra. vi & 3876 \\
\hline & c. 121 & & & & & & & c. 163 & \\
\hline & c. 122 & & & & & & & c. 165 & \\
\hline & c. 123 & & & & & & & (iv, c. 49x) & \\
\hline & c. 124 & & & & & & & & \\
\hline \multicolumn{10}{|c|}{ End of the first set of additions forming the "complete $T C$ ' } \\
\hline \multicolumn{10}{|c|}{ The Epistola Widonis; beginning of the 'TC core' } \\
\hline & c. 125 & & & & c. 58 & c. 35 & & (i, c. 61) & \\
\hline & c. 126 & fol. $89 \mathrm{v}$ & fol. 122r & fol. $95 \mathrm{v}$ & c. 1 & & c. 39 & c. 166 & \\
\hline & c. 127 & fol. $89 \mathrm{v}$ & fol. 122r & & c. 11 & c. 36 & c. 40 & (iii, c. 19) & \\
\hline & c. 128.1 & fol. $89 \mathrm{v}$ & fol. $122 \mathrm{v}$ & fol. $95 \mathrm{v}$ & c. 12 & c. $38 \mathrm{a}$ & c. 41 & c. 167.1 & \\
\hline & c. 128.2 & fol. $89 \mathrm{v}$ & fol. $122 \mathrm{v}$ & fol. $95 \mathrm{v}$ & c. 13 & c. $38 \mathrm{~b}$ & c. 42 & c. 167.2 & \\
\hline & c. 128.3 & & fol. $122 \mathrm{v}$ & foll. $95 / 96$ & c. 14 & c. 39 & c. $43.1 \mathrm{a}$ & c. 167.3 & \\
\hline & c. 128.4 & & fol. $122 \mathrm{v}$ & fol. $96 \mathrm{r}$ & c. 15 & c. $38 \mathrm{c}$ & c. $43.1 \mathrm{~b}$ & & \\
\hline & c. 128.5 & & fol. $122 \mathrm{v}$ & fol. 96r & c. 16 & c. $38 \mathrm{~d}$ & c. 43.2 & c. 167.4 & \\
\hline \multirow[t]{34}{*}{ c. 30} & c. $\left.128 \mathrm{~A}^{105}\right)$ & fol. $89 \mathrm{v}$ & fol. $122 \mathrm{v}$ & & c. 18 & & & & \\
\hline & c. 129.1 & fol. $89 \mathrm{v}$ & foll. $122 / 123$ & & & c. $40 \mathrm{a}$ & & c. 168.1 & \\
\hline & c. 129.2 & & & fol. 96r & & c. $40 \mathrm{~b}$ & & c. 168.2 & \\
\hline & c. 129.3 & & fol. 123r & fol. 96r & & c. $40 \mathrm{c}$ & & c. 168.3 & \\
\hline & c. 130 & fol. $89 \mathrm{v}$ & fol. 123r & & c. 19 & c. 41 & & c. 169 & \\
\hline & c. $130 \mathrm{~A}$ & fol. $89 \mathrm{v}$ & fol. 123r & & c. 20 & & & & \\
\hline & c. 131.1 & & fol. 123r & fol. 96r & c. 71.1 & c. 42 & & c. 170.1 & \\
\hline & c. 131.2 & & fol. 123r & fol. 96r & c. 71.2 & & & c. 170.2 & \\
\hline & c. 132 & & foll. 123/124 & fol. 96r & c. 73 & c. 43 & & c. 171 & \\
\hline & c. 133 & fol. 90r & fol. 124r & fol. 96r & c. 74 & & & c. 20 & \\
\hline & c. 134 & fol. 90r & fol. 124r & fol. 96rv & c. 75 & c. 44 & & c. 172 & \\
\hline & c. 135 & & fol. 124r & fol. 96v & c. 76 & & & c. 173.1 & \\
\hline & c. 136 & fol. 90r & fol. 124r & fol. 96v & c. 78 & & & c. 173.2 & c. 92 \\
\hline & c. 137 & & & fol. 96v & & & & c. 173.3 & \\
\hline & c. $137 \mathrm{~A}$ & fol. 90r & fol. 124r & fol. 96v & c. 79 & & & & \\
\hline & c. $137 \mathrm{~B}$ & fol. 90r & fol. 124r & fol. 96v & c. 80 & & & & \\
\hline & c. 138 & fol. 90r & fol. 124r & fol. 96v & c. 81 & c. 45 & & c. 174 & \\
\hline & c. 139 & fol. 90r & fol. 124r & & & c. 46 & c. 30 & c. 175 & \\
\hline & c. 140 & fol. 90r & fol. 124rv & & & c. 47 & & $(\mathrm{v}, \mathrm{c} .50 \mathrm{x})$ & \\
\hline & c. 141 & fol. 90r & fol. 124v & & & & & c. 176 & \\
\hline & c. 142 & fol. 90r & fol. $124 \mathrm{v}$ & & & c. 49 & & c. 177 & \\
\hline & c. 143 & & fol. $124 \mathrm{v}$ & & c. 82 & & & c. 178 & \\
\hline & c. 144 & & fol. $124 \mathrm{v}$ & & c. 83 & & & c. 179 & \\
\hline & c. 145 & fol.91v x & fol. 128rv x & & c. 36 & & c. 44 & c. 180 & \\
\hline & c. 146.1 & fol. $91 \mathrm{v}$ & & & c. 5 & c. $50 \mathrm{a}$ & c. 45 & c. 181 & \\
\hline & c. 146.2 & fol. 91v & & & & c. $50 \mathrm{~b}$ & c. 46 & & \\
\hline & c. $146.3 \mathrm{a}$ & fol. 91vx & & & c. $99 x$ & c. $50 \mathrm{c}$ & c. 47.1 & & \\
\hline & c. $146.3 \mathrm{~b}$ & fol. $91 \mathrm{v}$ & & & c. $99 \mathrm{x}$ & c. $50 \mathrm{~d}$ & c. 47.2 & & \\
\hline & c. $147.1 \mathrm{a}$ & fol. 90r & fol. $124 \mathrm{v}$ & & & & & c. 182.1 & \\
\hline & c. $147.1 \mathrm{~b}$ & fol. 90r & fol. $124 \mathrm{v}$ & & c. $4 \mathrm{x}$ & & & c. 182.2 & \\
\hline & c. $147.2 \mathrm{a}$ & fol. $90 \mathrm{v}$ & fol. $128 \mathrm{v}$ & & c. 38 & c. $51 \mathrm{a}$ & & c. $183 \mathrm{a}$ & \\
\hline & c. $147.2 \mathrm{~b}$ & fol. $91-2$ & foll. $128 / 129$ & & c. 39 & c. $51 \mathrm{~b}$ & & c. $183 \mathrm{~b}$ & \\
\hline & c. 148 & & & & & & & c. 184 & \\
\hline & c. 149.1 & & fol. 126rv & & c. 21 & c. $52 \mathrm{a}$ & & c. 185.1 & \\
\hline
\end{tabular}

$\left.{ }^{105}\right)$ Paris, BN lat. 13368, fol. 122v: Gregorius in suis decretis. Antiquorum patum regulam sequens nulli umquam - examine reatui subiacebit. 


\begin{tabular}{|c|c|c|c|c|c|c|c|c|c|}
\hline Quad. iv & 13368 & 14193 & 13413 & Antwerp & App. Seg. & Palermo & Trip. & Tarra. vi & 3876 \\
\hline & c. 149.2 & & fol. 126v & & c. 22 & c. $52 \mathrm{~b}$ & & c. 185.2 & \\
\hline & c. 150 & & fol. $126 \mathrm{v}$ & & c. 23 & c. 53 & & c. 186 & \\
\hline & c. 151 & & & & c. 8 & c. 55 & & c. 187 & \\
\hline & c. 152 & & & & c. 9 & c. 56 & & cc. $188-9$ & \\
\hline & c. $153 \mathrm{a}$ & fol. 91r & fol. $126 \mathrm{v}$ & fol. 97r & c. 24 & & & c. 190.1 & \\
\hline & c. $153 \mathrm{~b}$ & fol. 91r & fol. 126v & fol. 97r & c. 25 & & & c. 190.2 & \\
\hline & c. 154 & & fol. $125 r$ & & & c. 57 & & c. 191 & \\
\hline & c. 155.1 & fol. $90 \mathrm{v}$ & fol. 125r & & c. $84 \mathrm{a}$ & & & (i, c. 166a) & c. 51 \\
\hline & c. 155.2 & & fol. 125r & & c. $84 \mathrm{~b}$ & & & (i, c. 166b) & \\
\hline & c. 156 & & fol. $125 \mathrm{r}$ & & c. 85 & & & c. 192.1 & c. 52 \\
\hline & c. 157 & & fol. 125r & & c. 86 & & & c. 192.2 & \\
\hline & c. 158 & & & & c. 87 & & & c. 192.3 & \\
\hline & c. 159.1 & fol. 91r & fol. $126 \mathrm{v}$ & & c. 26 & c. $58 \mathrm{a}$ & & c. 17 & \\
\hline & c. 159.2 & fol. 91r & fol. $126 \mathrm{v}$ & & c. 27 & c. $58 \mathrm{~b}$ & & c. 193.1 & \\
\hline & c. 159.3 & & fol. 126v & & c. 28 & c. $58 \mathrm{c}$ & & c. 193.2 & \\
\hline & c. 160 & fol. 91r & fol. $126 \mathrm{v}$ & & c. 29 & & c. 48.1 & & \\
\hline & c. 161 & fol. 91r & foll. 126/127 & & c. 30 & & & c. 194 & \\
\hline & c. $162 \mathrm{a}$ & fol. 91r & fol. 127r & & c. 31 & & c. 48.2 & c. 195.1 & \\
\hline & c. $162 \mathrm{~b}$ & & fol. 127r & & c. 32 & & c. 48.3 & c. 195.2 & \\
\hline & c. $163 \mathrm{a}$ & & fol. $127 \mathrm{r}$ & & c. 33 & & & c. 196 & \\
\hline & c. $163 \mathrm{~b}$ & & fol. $127 \mathrm{r}$ & & & & & c. 197.1 & \\
\hline & c. 164 & & fol. 127r & & c. $34 \mathrm{a}$ & & & c. 197.2 & \\
\hline & c. 165.1 & fol. 91r & fol. $127 \mathrm{r}$ & & c. $34 \mathrm{~b}$ & & & c. 198.1 & \\
\hline & c. 165.2 & & & & & & & c. 198.2 & \\
\hline & c. 166 & fol. 92r & fol. 129rv & & & & c. 49 & & \\
\hline & c. $167 \mathrm{a}$ & & fol. 130r & & & & c. 50 & c. $199 \mathrm{a}$ & \\
\hline & c. $167 \mathrm{~b}$ & & fol. 130r & & & & c. 51 & c. $199 \mathrm{~b}$ & \\
\hline & c. 168.1 & & fol. $125 \mathrm{vx}$ & & & & & c. 200.1 & c. 93 \\
\hline & c. 168.2 & & fol. $125 \mathrm{v}$ & & & & & c. 200.2 & \\
\hline & c. 169.1 & & fol. $125 \mathrm{v}$ & fol. $96 \mathrm{v}$ & & & & c. 201.1 & c. 94 \\
\hline & c. 169.2 & foll. 90/91 & fol. $125 \mathrm{v}$ & fol. 96v & & & & c. 201.2 & c. 95 \\
\hline & c. 170 & fol. 91r & foll. $125 / 126$ & foll. $96 / 97$ & & & c. 52 & c. 202 & \\
\hline & c. 171 & fol. 91r & fol. 126r & fol. $97 \mathrm{r}$ & & & c. 53 & c. 203 & \\
\hline & c. 172 & fol. $90 \mathrm{v}$ & fol. 126r & fol. 97r & & & c. 54 & c. 204 & \\
\hline & c. 173 & fol. $90 \mathrm{v}$ & fol. 126r & fol. 97r & & & c. 55 & c. 205 & \\
\hline & c. 174.1 & fol. $90 \mathrm{v}$ & fol. 126r & & & & c. $56 \mathrm{a}$ & c. $111 \mathrm{x}$ & \\
\hline & c. 174.2 & fol. $90 \mathrm{v}$ & fol. 126r & & & & c. $56 \mathrm{~b}$ & & \\
\hline & c. 175 & & & & & & & c. 206 & \\
\hline & c. 176 & & & & c. 97 & & & c. 207 & \\
\hline & c. 177.1 & & (fol. 127v) & & c. 98 & & & c. 208.1 & c. 119 \\
\hline & c. 177.2 & & fol. $127 \mathrm{v}$ & & c. 94 & & & c. 208.2 & \\
\hline & c. 178 & fol. 91r & fol. $127 \mathrm{v}$ & & c. 95 & & & c. 209 & \\
\hline & c. 179 & fol. 91r & foll. $127 / 128$ & & c. 96 & & c. 57 & c. 210 & \\
\hline & c. 180 & fol. 92r & fol. 129r & & & & c. 58 & (i, c. 178) & \\
\hline & c. 181 & & & & c. 37 & & c. 59 & c. 211 & c. 53 \\
\hline & c. 182 & fol. 92r & fol. 129r & & & & c. 60 & c. 212 & c. 97 \\
\hline & c. 183 & fol. 92r & fol. 129r & & & & c. 61 & (i, c. $113 \mathrm{x}$ ) & \\
\hline & c. 184 & fol. 92r & fol. 129r & & c. 40 & & c. 62 & c. 213 & c. 36 \\
\hline & c. 185 & fol. 92r & fol. 129r & & & & c. 63 & c. 214 & \\
\hline & c. 186 & fol. 92r & fol. 129r & & c. 41 & & c. 64 & c. 215 & \\
\hline & c. 187 & & fol. $129 \mathrm{v}$ & & c. 42 & & c. 65 & c. 216 & \\
\hline
\end{tabular}




\begin{tabular}{|c|c|c|c|c|c|c|c|c|c|}
\hline Quad. iv & 13368 & 14193 & 13413 & Antwerp & App. Seg. & Palermo & Trip. & Tarra. vi & 3876 \\
\hline & $\begin{array}{l}\text { c. } 188 \\
\end{array}$ & fol. 92r & fol. $129 \mathrm{v}$ & & & & c. 66 & c. 217 & \\
\hline & & & fol. 130r & & & & & & \\
\hline & c. 189 & & & & & & & c. 36 & \\
\hline c. 347 & c. 190 & & fol. 130r x & & c. 77 & & c. 67 & (iv, c. 69) & \\
\hline & c. 191 & & fol. 130r & & & & c. 68 & c. 218 & \\
\hline & c. 192 & & fol. 130rv & & & cc. $60-1$ & & c. 219 & \\
\hline & c. $\left.192 \mathrm{~A}^{106}\right)$ & & fol. $130 \mathrm{v}$ & & c. 44 & & & & \\
\hline & c. 193 & & fol. $122 \mathrm{r} \mathrm{x}$ & & & c. 62 & & c. 220 & \\
\hline & c. 194 & & & & c. 10 & c. 63 & & c. 221 & \\
\hline & c. 195.1 & & & & & & c. 69.1 & c. 222.1 & \\
\hline & c. 195.2 & & & & & & c. 69.2 & c. 222.2 & \\
\hline & c. 195.3 & & & & & & c. 69.3 & c. 222.3 & \\
\hline & c. $196.1 \mathrm{a}$ & & fol. 127r & & c. 69 & & & c. $223.1 \mathrm{a}$ & \\
\hline & c. $196.1 \mathrm{~b}$ & & fol. 127r & & & c. $64 \mathrm{a}$ & & c. $223.1 \mathrm{~b}$ & \\
\hline & c. 196.2 & & fol. 127r & & & c. $64 \mathrm{~b}$ & & c. 223.2 & \\
\hline & c. $196.2 \mathrm{~A}$ & & fol. 127r & & & & & & \\
\hline \multicolumn{10}{|c|}{ End of the ' $T C$ core' } \\
\hline \multicolumn{10}{|c|}{ Beginning of the second set of additions forming the "complete $T C$ ' } \\
\hline & c. 197 & & & & & c. 65 & & c. 224 & \\
\hline & c. 198 & & & & & & & c. 225 & \\
\hline & c. 199 & fol. $89 \mathrm{v} \mathrm{x}$ & & & & & c. 77 & & c. 101 \\
\hline & c. $200 \mathrm{a}$ & & & & & & & & \\
\hline & c. $200 \mathrm{~b}$ & & & & & & & & \\
\hline & c. 201 & & & & & & & (ii, c. 2) & \\
\hline & c. 202 & & & & & & & & c. 34 \\
\hline & c. 203 & & & & & & & c. 226 & \\
\hline & c. 204 & & & & & & & (ii, c. 12) & \\
\hline & c. 205 & & & & & & & & \\
\hline & c. 206 & & & & & & & & \\
\hline & c. 207.1 & & & & & & & c. 227.1 & \\
\hline & c. 207.2 & & & & & & & c. 227.2 & \\
\hline & c. 208 & & & & & & & c. 228 & \\
\hline & c. 209 & & & & & & & c. 229 & \\
\hline & c. 210 & & & & & cc. $66-7$ & & c. 230 & \\
\hline & c. $211.1 \mathrm{a}$ & & & & c. 91 & & c. 70 & c. 231.1 & \\
\hline & c. $211.1 \mathrm{~b}$ & & & & c. $92 x$ & & c. 71 & c. 231.2 & \\
\hline & c. $211.1 \mathrm{c}$ & & & & & & c. 72 & c. 231.3 & \\
\hline & c. 211.2 & & & & & & c. 73 & c. 231.4 & \\
\hline & c. 211.3 & & & & c. 93 & & c. 74 & c. 231.5 & \\
\hline & c. $211 \mathrm{~A}$ & fol. $94 \mathrm{r}$ & & & & & c. 75 & & \\
\hline & c. $211 \mathrm{~B}$ & foll. 94/95 & & & & & c. 76 & & \\
\hline & c. 212 & fol. $92 \mathrm{v}$ & & & c. 62 & & & c. 232 & \\
\hline & c. 213 & & & & & & & c. 233 & \\
\hline & c. 214 & & & & c. 100 & & & c. 234 & \\
\hline & c. 215.1 & & & & & & & (i, c. 157) & \\
\hline & c. 215.2 & & & & & & & & \\
\hline & c. 216 & & & & & & & & \\
\hline & c. 217 & & & & & & & c. 235 & \\
\hline
\end{tabular}

$\left.{ }^{106}\right)$ Paris, BN lat. 13368 fol. 130v: Gregorius Vitali defensori. De hoc quod scripsisti fratrem et - atque securitate communicent. 


\begin{tabular}{|c|c|c|c|c|c|c|c|c|c|}
\hline Quad. iv & 13368 & 14193 & 13413 & Antwerp & App. Seg. & \begin{tabular}{|l|} 
Palermo \\
\end{tabular} & Trip. & Tarra. vi & 3876 \\
\hline & c. 218 & & & & & & & c. 12 & c. 111 \\
\hline & c. 219 & & & & & & & & \\
\hline & c. $220 \mathrm{x}$ & & & & & & & & \\
\hline & c. 221 & & & & & & & & \\
\hline & c. 222 & & & & & & c. 78 & c. 236 & \\
\hline & c. 223 & & & & & & & c. 237 & \\
\hline & c. 224 & & & & & & & c. 238 & c. 115 \\
\hline & c. 225 & & & & & & & c. 239 & \\
\hline & c. 226 & & & & & & & c. 240 & \\
\hline & c. 227.1 & & & & & & & c. 241.1 & c. $289 \mathrm{x}$ \\
\hline & c. 227.2 & & & & & & & c. 241.2 & c. $228 \mathrm{x}$ \\
\hline & c. 228 & & & & & & & c. 241.3 & \\
\hline & c. 229 & & & & & & c. 79 & c. 112 & \\
\hline & c. 230 & & & & & & c. 80 & (iv, c. 33) & c. 68 \\
\hline & c. 231 & & & & & c. 68 & & c. 242 & c. 69 \\
\hline & c. 232 & & & & & c. 69 & & c. 243 & \\
\hline & c. 233 & & & & c. 101 & c. 70 & & c. 244 & c. 54 \\
\hline & c. 234.1 & & & & c. 102 & c. 71 & & c. 245 & c. 55 \\
\hline & c. 234.2 & & & & c. 68 & & & c. 246 & c. 56 \\
\hline & c. 235 & & & & & & c. 81 & c. 247 & \\
\hline & c. 236 & & & & & & & (ii, c. 61) & \\
\hline & c. 237 & & & & & & & & \\
\hline & c. 238 & & & & c. 7 & & & c. 248 & \\
\hline & c. 239 & & & & & & & c. 249 & c. 70 \\
\hline & c. 240 & & & & & & & (i, c. 124) & \\
\hline \multicolumn{10}{|c|}{ End of the 'complete $T C$ ' } \\
\hline \multicolumn{10}{|c|}{ Beginning of the additions forming the 'augmented $T C$ ' } \\
\hline \multirow[t]{2}{*}{ c. 11} & c. 241 & & & & & & & & \\
\hline & c. 242 & & & & & & & & \\
\hline c. 10 & c. 243 & & & & & & & (iv, c. 39) & \\
\hline c. 14 & c. 244 & & & & & & & & \\
\hline c. $16 \mathrm{x}$ & c. 245 & & & & & & & c. 250 & \\
\hline c. 37 & c. 246 & & & & & & & & \\
\hline \multirow[t]{2}{*}{ c. $35 \mathrm{x}$} & c. 247 & & & & & & & c. 251 & \\
\hline & c. 248 & & & & & & & c. 252 & \\
\hline c. 43 & c. 249 & & & & & & & & \\
\hline c. 54 & c. 250 & & & & & & & & c. 120 \\
\hline $\begin{array}{l}\text { c. } 57 \\
\text { c. } 55\end{array}$ & c. 251 & & & & & & & & c. 121 \\
\hline c. 63 & c. 252 & & & & & & & & \\
\hline c. 67 & c. 253 & & & & & & & & c. 122 \\
\hline c. 69 & c. 254 & & & & & & & & \\
\hline c. 272 & c. 255 & & & & & & & & c. 71 \\
\hline c. 31 & c. 256 & & & & & & & & \\
\hline \multirow[t]{4}{*}{ c. 78} & c. 257 & & & & & & & & \\
\hline & c. 258 & & & & & & & & \\
\hline & c. 259 & & & & & & & (iv, c. $38 \mathrm{x}$ ) & \\
\hline & c. 260 & & & & & & & c. 253 & \\
\hline \multirow[t]{2}{*}{ c. 70} & c. 261 & & & & & & & c. 254 & \\
\hline & c. 262 & & & & & & & & \\
\hline c. 72 & c. 263 & & & & & & & & \\
\hline c. 74 & c. 264 & & & & & & & & \\
\hline
\end{tabular}




\begin{tabular}{|c|c|c|c|c|c|c|c|c|c|}
\hline Quad. iv & 13368 & 14193 & 13413 & Antwerp & App.Seg. & Palermo & Trip. & Tarra. vi & 3876 \\
\hline c. $177 \mathrm{x}$ & c. 265 & & & & & & & & \\
\hline c. 183 & c. 266 & & & & & & & c. 3 & c. 72 \\
\hline c. 245 & c. 267 & & & & & & & & c. 73 \\
\hline c. 277 & c. 268 & & & & & & & & \\
\hline \multirow[t]{2}{*}{ c. 278} & c. 269 & & & & & & & & \\
\hline & c. 270 & & & & & & & & \\
\hline \multirow[t]{2}{*}{ c. 260} & c. 271 & & & & & & & & \\
\hline & \begin{tabular}{|l|} 
c. 272 \\
\end{tabular} & & & & & & & & \\
\hline \multirow[t]{6}{*}{ c. 181} & c. 273 & & & & & & & & c. 75 \\
\hline & c. 274 & & & & & & & c. 15 & c. 112 \\
\hline & c. 275 & & & & & & & & \\
\hline & c. 276 & & & & & & & & \\
\hline & c. 277 & & & & & & & & \\
\hline & c. 278 & & & & & & & & \\
\hline c. 370 & c. 279 & & & & & & & & c. 77 \\
\hline \multirow[t]{5}{*}{ c. 368} & c. 280 & & & & & & & & \\
\hline & \begin{tabular}{|l|} 
c. 281 \\
\end{tabular} & & & & & & & & \\
\hline & c. 282 & & & & & & & & c. 23 \\
\hline & c. 283 & & & & & & & & \\
\hline & c. 284 & & & & & & & & \\
\hline c. 307 & c. 285 & & & & & & & & \\
\hline c. 210 & c. 286 & & & & & & & & \\
\hline c. 211 & c. 287 & & & & & & & & \\
\hline c. 39 & \begin{tabular}{|l|} 
c. 288 \\
\end{tabular} & & & & & & & & \\
\hline c. 186 & c. 289 & & & & & & & & \\
\hline c. 195 & c. 290 & & & & & & & & c. 99 \\
\hline c. 201 & \begin{tabular}{|l|} 
c. 291 \\
\end{tabular} & & & & & & & & \\
\hline c. 315 & c. 292 & & & & & & & c. 255 & \\
\hline c. 316 & c. 293 & & & & & & & c. 256 & \\
\hline c. 173 & c. 294 & & & & & & & c. 257 & c. 79 \\
\hline c. 175 & c. 295 & & & & & & & c. 258 & c. 80 \\
\hline \multirow[t]{2}{*}{ c. 367} & c. 296 & & & & & & & c. 259 & \\
\hline & c. 297 & & & & & & & c. 260 & c. 82 \\
\hline c. 288 & c. 298 & & & & & & & c. 261 & \\
\hline c. 349 & \begin{tabular}{|l|} 
c. 299 \\
\end{tabular} & & & & & & & c. 262 & \\
\hline \multirow[t]{2}{*}{ c. 58} & c. 300 & & & & & & & c. 263 & \\
\hline & c. 301 & & & & & & & c. 264 & \\
\hline c. 225 & c. 302 & & & & & & & c. 265 & \\
\hline c. 226 & c. 303 & & & & & & & c. 266 & \\
\hline \multicolumn{10}{|c|}{ End of the 'augmented $T C$ ' } \\
\hline \multicolumn{10}{|c|}{ Beginning of the additions found only in BN lat. 13368} \\
\hline & c. 304 & & & & & & & & \\
\hline & c. 305 & & & & & & & & \\
\hline & c. 306 & & & & & & & & \\
\hline & c. 307 & & & & & & & & \\
\hline & c. 308 & & & & & & & & \\
\hline & c. 309 & & & & & & & & \\
\hline & c. 310 & & & & & & & & \\
\hline & c. 311 & & & & & & & & \\
\hline & c. 312 & & & & & & & & \\
\hline & c. 313 & & & & & & & & \\
\hline
\end{tabular}




\begin{tabular}{|c|c|c|c|c|c|c|c|c|c|}
\hline Quad. iv & 13368 & 14193 & 13413 & Antwerp & App. Seg. & Palermo & Trip. & Tarra. vi & 3876 \\
\hline & c. 314 & & & & & & & & \\
\hline & c. 315 & & & & & & & & \\
\hline & c. 316 & & & & & & & & \\
\hline & c. 317 & & & & & & & & \\
\hline & c. 318 & & & & & & & & \\
\hline & c. 319 & & & & & & & & \\
\hline & c. 321 & & & & & & & & \\
\hline & c. 322 & & & & & & & & \\
\hline & c. 323 & & & & & & & & \\
\hline & c. 324 & & & & & & & & \\
\hline & c. 325 & & & & & & & & \\
\hline & c. 326 & & & & & & & & \\
\hline & c. 327 & & & & & & & & \\
\hline & c. 328 & & & & & & & & \\
\hline & c. 329 & & & & & & & & \\
\hline & c. 330 & & & & & & & & \\
\hline & c. 331 & & & & & & & & \\
\hline & c. 332 & & & & & & & & \\
\hline & c. 333 & & & & & & & & \\
\hline & c. 334 & & & & & & & & \\
\hline & c. 335 & & & & & & & & \\
\hline & c. 336 & & & & & & & & \\
\hline & c. 337 & & & & & & & & \\
\hline & c. 338 & & & & & & & & \\
\hline Fnd & e collect & N I t & & & & & & & \\
\hline
\end{tabular}

